\title{
0 uso de citações, alusões e ecos do Antigo Testamento na epístola de Paulo aos Romanos
}

\section{WALDECIR GONZAGA \\ DIEGO DA SILVA RAMOS ${ }^{2}$ \\ YGOR ALMEIDA DE CARVALHO SILVA ${ }^{3}$}

Resumo: O presente artigo objetiva analisar o uso de citações, alusões e ecos do Antigo Testamento na epístola de Paulo aos Romanos. Utilizam-se os critérios apontados por Richard Hays e G. K. Beale em suas obras. O estudo faz uma introdução acerca do uso do AT no NT, no epistolário paulino e, mais especificamente, em Romanos, apresentando um quadro contendo os textos onde Paulo faz uso do AT nesta epístola. As conclusões da pesquisa apontam que Paulo não fazia uso do AT de modo aleatório, mas proposital, a partir de um pensamento comum ao judaísmo do primeiro século. A pesquisa evidencia, ainda, a prevalência do uso da Septuaginta (LXX) em detrimento do Texto Hebraico (TH) e que, mesmo nos textos onde se faz referência direta ao TH, é possível relacioná-lo à LXX, configurando, desse modo, o uso corrente e prioritário desta versão das Escrituras em Romanos, o que também ocorre em outras cartas paulinas e livros do NT. O objetivo principal deste estudo é entender como e porque Paulo usou tão exaustivamente as Escrituras de Israel nesta que foi a maior de suas cartas.

Palavras-Chave: Citações; alusões e ecos; uso do Antigo Testamento no Novo Testamento; Paulo; Romanos.

\section{The use of quotations, allusions and echos of the Old Testament in Paul's Epistle to the Romans}

\footnotetext{
Abstract: This article aims to analyze the use of the quotations, allusions and echos of the Old Testament in Paul's Epistle to the Romans. We use the criteria pointed out by Richard Hays and G.

1 Doutor em Teologia Bíblica pela Pontifícia Universidade Gregoriana, Roma. Diretor e Professor de Teologia Bíblica do Departamento de Teologia da PUC-Rio. E-mail: waldecir@hotmail.com

2 Mestrando em Teologia Bíblica pela Pontifícia Universidade Católica do Rio de Janeiro. Bacharelado em Teologia pela Faculdade Teológica Sul Americana. E-mail: prdiegoramos@outlook.com

${ }^{3}$ Mestrando em Teologia Bíblica pela Pontifícia Universidade Católica do Rio de Janeiro. Bacharelado em Teologia pelo Centro Universitário Adventista de São Paulo. E-mail: ygor.almeida@adventistas.org
} 
K. Beale in their works. The study introduces the use of the OT in the NT, in the Pauline epistolary and, more specifically, in Romans, presenting a table containing the texts where Paul uses the OT in this epistle. The research findings point out that Paul did not use the OT at random, but on purpose, based on a thought common to the Judaism in the first century. The re:search also shows the prevalence of the use of the Septuagint (LXX) to detriment of the Hebrew Text (TH) and that, even in the texts where reference is made directly to the TH, it is possible to relate it to the LXX, thus configuring the current and priority use of this version of Scripture in Romans, which also occurs in other Pauline letters and NT books. The main objective of this study is to understand how and why Paul used the Scriptures of Israel so extensively in this one that was the greatest of his letters.

Keywords: Quotations; allusions and echos; use of the Old Testament in the New Testament; Paul; Romans.

Nosso objetivo é oferecer uma apresentação de como Paulo usou o AT em sua epístola aos Romanos, tida como uma epístola autenticamente paulina pela maioria dos críticos (GONZAGA, 2017, p. 19-41), inclusive por Marcião e por Lutero, e que aparece nas listas de todos os cânones do NT, do Fragmentum Muratotianum até a Reforma (GONZAGA, 2019). Se não bastasse isso, a espístola aos Romanos é de fato a obra-prima de Paulo, a ponto de ter sido vista pela reforma como o compendium paulino de dourina cristã (WILCKENS, 1997, p. 27), ideia essa que não é compactuada por Schlier (1982, p. 37), que afirma que "Paulo trata dos temas da fé cristã, mas não faz uma exposição sistemática”.

Por que um estudo referente ao uso do AT no NT, como este em Romanos, é importante? Isso se justifica porque os autores neotestamentários usaram de modo abundante o AT ao realizarem a redação de seus escritos. A profunda dependência literária que eles tiveram da lei, dos profetas e dos escritos, salta aos olhos de qualquer leitor da Bíblia. Aliás, o uso de frases do AT ao longo do NT, é encontrado até mesmo na boca de Jesus, como nos textos das tentações no deserto, seja em Mateus 4:1-11, ou em Lucas 3:1-13, entre tantos outros textos ao longo dos evangelhos.

Os evangelistas, ao narrarem a vida de Cristo, o fizeram, em vários momentos, numa relação com o AT, numa linha de promessa e de cumprimento (Mt 2:15-18; 24: 26; 27:9-10; Mc 1:2-3; Jo 19:24, 28 e 36). Bem verdade é que eles não conheciam e nem trabalhavam com as elaboradas regras de exegese e de hermenêutica dos teólogos do século XVIII para cá. Em alguns momentos, o uso que os autores do NT fazem do testemunho veterotestamentário se assemelha, ora a uma analogia ou alegoria; ora a um pesher (interpretação) da comunidade de Qumran; e, em outros casos, a uma exegese derásica, feita pelos rabinos, como um midrash (explanação das Escrituras) (ROBERTSON, 1996, p. 17-19; PENNA, 2013, p. 66). Contudo, eles viam em Jesus de Nazaré o centro ao redor do qual gravitam as profecias e as tipologias veterotestamentárias. Aliás, "o ponto de partida da carta é a cristologia" (MOO, 2014, p. 52).

O uso do AT no NT pode ser verificado ainda nas pregações dos apóstolos, que encontramos ao longo do livro de Atos $(2: 16-21,25-28,34-35 ; 3: 22-25 ; 7,42-43,48-50)$. À mesma conclusão se pode chegar pela leitura das cartas neotestamentárias. Via de regra, quando elas se referem à Escritura inspirada (2Tm 3:15-16; 2Pe 1:20-21) é do AT que estão falando. "Um Novo Testamento separado do Antigo anula a si mesmo, pois ele só existe, de acordo com sua própria pretensão, mediante esta unidade" (RATZINGER, 2010, p. 19). 


\title{
O uso do AT nas cartas paulinas
}

Paulo é o primeiro autor do NT a redigir um escrito. Portanto, ele escreveu numa época em que ainda não havia o NT, "nem um corpo dos escritos cristãos reconhecidos como normativos, sua Escritura era o corpo de escritos que constituía o texto sagrado de Israel, que os cristãos posteriormente vieram a chamar de Antigo Testamento" (HAYS, 1989, p. x). Somente o Corpus Paulinum faz cerca de 100 referências ao AT (BEALE, 2014, p. 55).

As citações de Paulo em geral seguem a Septuaginta (LXX), a tradução grega da Bíblia Hebraica, datada entre o $3^{\circ}$ e o $2^{\circ}$ século a.C., que era comumente usada nas sinagogas helenísticas no tempo de Cristo. Raramente as citações de Paulo concordam com o Texto Hebraico (TH) em comparação com a LXX. Segundo Fitzmyer (1993, p. 34), o fato de Paulo usar com predominância a LXX, evidencia que a "comunidade cristã de Roma era formada prevalentemente de ex-pagãos que tinham familiaridade com a LXX", demonstrando conhecer mais o texto bílico a partir da versão grega e não tanto das fontes hebraicas.

Em contraste, em Roma também havia uma população considerável de judeus (LÉGASSE, 2002, p. 30; DUNN, 1988, p. liii). Ao que tudo indica, Paulo, cuja atividade missionária focava-se mais em congregações gentílicas da Ásia Menor e da Grécia, tinha o hábito de ler e citar a Escritura em grego, que era o idioma comum na parte oriental do império romano (HAYS, 1989, p. x-xi). Segundo Penna (2013, p. 66-67), "a reutilização do texto da LXX, desempenha, sem dúvida, uma clara função argumentativa da fé cristológica fundamental do Apóstolo”, que procura fundamentar tudo nas tradições paternas de Israel.

A razão exata para o uso da LXX estava fundamentada no empreendimento missionário dos evangelistas e apóstolos da igreja primitiva. A tradução grega do AT já havia encontrado seu caminho em cada cidade do império romano para a qual os judeus da diáspora tinham ido (ARCHER; CHIRICHIGNO, 1983, p. 2; LÉGASSE, 2002, p. 29; DUNN, 1988, p. xliv-liv). Como bem nos recordam Archer e Chirichigno:

\begin{abstract}
Virtualmente, esta era a única forma do Antigo Testamento nas mãos dos crentes judeus fora da $\mathrm{Pa}$ lestina; e era certamente também a única forma disponível para os convertidos às fés jucaica ou cristã. Os apóstolos estavam propagando um evangelho que apresentava Jesus Cristo como cumprimento das promessas messiânicas do Antigo Testamento. Suas audiências no mundo do Oriente Médio e Mediterrâneo ouviam que bastava-lhes apenas consultar seu Antigo Testamento para verificar a veracidade dos reclamos apostólicos de que Jesus, por sua pessoa e sua obra, cumprira as promessas de Deus (ARCHER; CHIRICHIGNO, 1983, p. 2).
\end{abstract}

A compreensão do uso que Paulo fez do AT pode ajudar a elucidar questões que ele trata em suas cartas, como os princípios da criação, o problema do pecado, a justiça pela fé, o papel da lei e das obras na vida do crente, a eleição de Israel, o relacionamento entre judaísmo e cristianismo, a autoridade das Escrituras, o papel da igreja como comunidade interpretativa, as liberdades e os limites em operação nas comunidades para as quais ele escreve.

Uma pergunta pertinente a se fazer sempre é: como Paulo interpretava as Escrituras? Apesar de haver alguma semelhança em um ponto ou outro, ele se distanciava tanto da exegese alegórica dos judeus helenistas de Alexandria, quanto dos pesharim (interpretações), que eram comentários versículo por versículo do AT, feitos pela comunidade de Qumran; também se distanciava 
das ampliações e embelezamentos das narrativas canônicas, promovidos pelos livros apócrifos. Paulo cita vários relatos bíblicos desde a criação como sendo históricos $(\mathrm{Rm} 1: 20,25 ; 5: 12,14$ 15, 17-19; 1Co 10:1-11; 2Co 3:13-14; Gl 3:6, 14, 18-19; 5:22-25, 28-31); mas sua exposição não se limita a um dossiê, como a obra Antiguidades Judaicas, de Flávio Josefo; antes, faz aplicações homiléticas, extraindo desses relatos lições espirituais (SILVA, 2008, p. 83-84, 86).

Contudo, não se pode negar que ele refletia, até certa medida, a cultura religiosa judaica de sua época, e, portanto, um pouco da exegese rabínica, conhecida como derásica, transparente nos midrashim (explanações das Escrituras). Tendo sido "educado aos pés de Gamaliel” (At 22:3), com certeza recebeu uma influência da escola rabínica de Hilel, a mais forte do judaísmo em seus dias. Entretanto, Silva (2008, p. 84-91) ressalva que, assim como os evangelistas e demais autores do NT, a exegese de Paulo se diferenciava da dos rabinos em três pontos principais: (1) de forma geral, cotumava respeitar mais o contexto original das perícopes (ainda que não nos moldes da exegese moderna); (2) era cristocêntrica; e (3) eclesiocêntrica, ou seja, via em Cristo (como sumo-sacerdote e cordeiro) e na Igreja (como povo), a relação de continuidade da aliança, de promessa e cumprimento da tipologia veterotestamentária. Aliás, Paulo não teve dúvidas em olhar para o centro da morte expiatória de Cristo em prol de salvação do ser humano, como o temos em Romanos 1-5 (WILCKENS, 1997, p. 46).

\section{0 método exegético do uso do AT no NT}

Nossa análise segue a linha de pesquisa conforme o método do uso do AT no NT a partir dos critérios levantados por dois autores: R. Hays e G. K. Beale. Esses autores desenvolveram os passos do método do uso do AT no NT, aplicável a todos os livros do NT e não apenas às cartas paulinas. Hays (1989, p. 29-32), por exemplo, fornece sete critérios para se atestar o uso de uma passagem do AT no NT, inclusive para se detectar uma citação, alusão ou eco:

1. Disponibilidade: estaria a fonte em questão disponível ao autor e aos leitores originais?

2. Volume: quão distinto ou proeminente é o texto precursor dentro da Escritura, e quanta ênfase retórica ele recebe na obra daquele escritor específico?

3. Recorrência: com que frequência o mesmo autor faz alusão àquela passagem escriturística mediante outras passagens bíblicas?

4. Coerência temática: como a alegada alusão se encontra dentro da linha de argumentação que aquele escritor está desenvolvendo?

5. Plausibilidade histórica: teria o escritor pretendido o alegado efeito de significado? Teriam seus leitores originais tido esta compreensão?

6. História da interpretação: teriam outros leitores, críticos e pré-críticos, ouvido os mesmos ecos do AT? 
7. Satisfação: a interpretação proposta faz realmente sentido? Ela ilumina e esclarece o contexto? Traz para o leitor a explicação satisfatória, oriunda da relação intertextual?

Beale (2013, p. 68-69), por sua vez, propõe nove passos para se interpretar o uso do AT no NT, seguindo os passos de Hays, também na tentativa de especificar o uso de citação, alusão ou eco:

1. Identificar a referência ao AT, se é uma citação, alusão ou eco; neste primeiro passo são retomados os 7 critérios de Hays, sendo os demais propostos por Beale;

2. Analisar o contexto geral do NT em que ocorre a referência ao AT;

3. Analisar o contexto imediato e o geral do AT, interpretando atenta e minuciosamente sobretudo o parágrafo em que a citação ou alusão ocorre;

4. Pesquisar o uso do texto do AT no judaísmo anterior e posterior, que possa ser importante para a apropriação do texto veterotestamentário pelo NT;

5. Comparar os textos (inclusive suas variantes textuais): Novo Testamento, Septuaginta, Texto Massorético e os Targumim, citações judaicas antigas (Manuscritos do Mar Morto, Pseudepígrafos, Josefo, Filo etc.);

6. Analisar o uso textual que o autor faz do AT;

7. Analisar a interpretação (hermenêutica) que o autor faz do texto do AT;

8. Analisar o uso teológico que o autor faz do AT;

9. Analisar o uso retórico que o autor faz do AT.

\section{Citações, alusões, ecos e suas ocorrências em Romanos}

Existem, pelo menos, três formas diferentes pelas quais os autores neotestamentários se referiram ao AT: citação, alusão e eco. Citação é a referência direta, uma reprodução explícita de uma passagem do AT,

facilmente identificável por seu paralelismo vocabular bem característico. Muitas dessas citações são introduzidas por uma fórmula do tipo "para que se cumprisse o que o Senhor havia falado pelo profeta" (Mt 2:15), "está escrito" (Rm 3:4), ou uma expressão semelhante. Outras passagens sem esses indicadores prévios apresentam paralelos tão óbvios com algum texto do AT que só podem se tratar de citação (v. p. ex. Gl 3:6; Ef 6:3) (BEALE, 2013, p. 53).

Outro exemplo de citação: "Ele respondeu: Não lestes que desde o princípio o Criador os fez homem e mulher? E que disse: Por isso o homem deixará pai e mãe e se unirá à sua mulher, e 
os dois serão uma só carne?” (Mt 19:4-5; cf. Gn 1:27; 2:24). Ademais, existem ainda outras formas de citação, menos explícitas e diretas, que podem ser conferidas ao longo de todo o NT.

Às vezes, a fórmula clássica de introdução pode ser substituída por uma clara explicação interpretativa (cf. 1Co 15:27) ou por uma brusca transição sintática ou estilística entre o texto citado e o contexto no qual é introduzido (cf. Rm 9:7). Em todo caso, necessita-se de uma indicação explícita literária de que neste ponto o autor pretende reproduzir palavras de outra fonte (BELLI et al., 2006, p. 27-28).

A alusão é uma referência indireta, praticamente certa ou provável, embora não tão material quanto a citação explítica. Em outras palavras, para se identificar uma alusão, é necessário atestar a existência de "um paralelo incomparável ou único de redação, sintaxe, conceito ou conjunto de motivos na mesma ordem ou estrutura. Quando se encontram tanto uma redação (coerência vocabular) quanto temas singulares, a alusão proposta ganha maior probabilidade" (BEALE, 2013, p. 56).

Um exemplo claro de alusão é o discurso de Estêvão em Atos 7. Ali, o primeiro mártir cristão, em sua resposta ao Sinédrio, relembra a história de vários personagens marcantes da trajetória do povo hebreu, começando por Abraão e indo até Salomão, aludindo, de forma instrutiva, às narrações escriturísticas. Na última parte do seu discurso (At 7:42-50), Estêvão se preocupa em enfatizar que está se referindo ao texto sagrado.

Há dois livros neotestamentários que chamam a atenção também pela quantidade de vezes que recorrem ao material específico do AT mediante a alusão: a epístola aos Hebreus, tecida pelas temáticas presentes no livro de Levítico; e o livro do Apocalipse, recheado de termos e conteúdos do livro de Daniel. "Outros exemplos são: Mateus 9:13 = Oseias 6:6; Lucas 13:35 = Salmo 118:26; Romanos 2:6 = Salmo 62:13; 2Tessalonicenses 2:8 = Isaías 11:4” (BELLI et al., 2006, p. 32).

Por outro lado, o eco significa uma vaga lembrança de uma passagem ou conceito veterotestamentário, um tipo de alusão possível (BEALE, 2013, p. 56) 4 $^{4}$ Para ilustrar o que é um eco do AT no NT, tomemos a perícope do nascimento de João Batista (Lc 1:57-80). Ao lermos atentamente essa passagem, percebemos, pelo menos, dois ecos das Escrituras Hebraicas: um do Êxodo e outro do nascimento de Samuel.

1. Do Êxodo: (a) O Senhor visita seu povo (Lc 1:68 // Êx 3:16); (b) Deus se lembra da aliança que fez aos patriarcas do seu povo, especialmente Abraão (Lc 1:72, 73 // Êx 6:29); (c) o Senhor liberta seu povo (Lc 1:71 // Exx 3:7-10); (d) o Senhor salva/redime seu povo (Lc 1:68, 69, 77 // Êx 15:2); e (e) o profeta vai para o deserto e ali Deus o prepara para sua manifestação a Israel (Lc 1:80 // Êx 3:1).

2. Do nascimento de Samuel: (a) contexto de esterilidade (Lc 1:7, 18 // 1Sm 1:2, 5-6); (b) a lembrança de Deus (Lc 1:72 // 1Sm 1:19); (c) alegria pelo nascimento do bebê (Lc 1:14, 58 // 1Sm 2:1); (d) canção de ação de graças após o nascimento do bebê (Lc 1:67-79 // 1Sm 2:1-10); (e) João Batista era de linhagem sacerdotal e Samuel foi feito sacerdote (Lc

4 Para mais detalhes sobre o eco, consulte Beetham (2008, p. 20-24). Beetham estabelece quatro itens que considera essenciais para a compreensão do que vem a ser um eco: (1) nem sempre é um ato consciente, (2) tem sempre uma fonte identificável, (3) o autor não intenciona apontar para a sua audiência o precursor daquela mensagem e (4) pode não vir conectado ao contexto original do texto ecoado. Ainda, para Beetham o eco vem à tona porque a mente do autor está saturada por aquela fonte (p. 21). 
1:5 // 1Sm 1:18); (f) o refrão do crescimento físico e espiritual (Lc 1:80 // 1Sm 2:21, 26); e (g) o filho se tornou um profeta (Lc 1:76 // 1Sm 3:19 - 21).

\section{Quadro do uso do AT em Romanos}

No que tange a referências do AT, Romanos computa cerca 60 (SEIFRID, 2014, p. 759; ROBERTSON, 1996, p. 142)5 , o que representa mais da metade das que são feitas em todo o epistolário paulino. Entretanto, além das muitas citações, uma parte significativa do vocabulário teológico da epístola pertence ao campo das alusões. Termos como "promessa", "fé", "chamado", "aliança", "lei", "patriarcas", e tantos outros, têm suas raízes nos textos veterotestamentários, relembrando o contexto de onde foram extraídos. Aliás, como nos recorda Pitta (2014, p. 28), "em nenhuma carta como em Romanos, Paulo recorre ao uso abundamente do AT".

Há também ecos, como: a decadência da humanidade idólatra (Rm 1:18-32), Adão e sua transgressão (Rm 5:12-21) e a confrontação humana com a lei de Deus (Rm 7:7-25), relembrando a narrativa de Gênesis 3, sem citar esse texto. Outro eco é transmitido em Romanos 3:21-26, na descrição da justificação que Deus realiza em nós po intermédio de Cristo, rica em recursos de textos litúrgicos e promessas proféticas, sem citar de maneira explícita nenhum texto veterotestamentário. Segundo Seifrid (2014, p. 759), "Como Paulo deixa claro na introdução desta epístola, sua mensagem à igreja de Roma é nada mais que a proclamação das Escrituras cumpridas no Cristo encarnado, crucificado e ressurreto."

Queremos dar um passo a mais e conferir todas referências do AT na epístola aos Romanos, identificando quais são as citações, alusões ou ecos. Além disso, outro dado muito interessante é ir verificando a fonte que Paulo usou, se a partir do texto grego (LXX) ou da fonte hebraica (TH). Para tanto, ofereceremos os textos nas línguas originais, uma tradução e a indicação de que fonte se trata (LXX ou TH), a fim de melhor ajudar na leitura do quadro. Do ponto de vista quantitativo, o autor mais citado é Isaías, seguido dos livros de Salmos, Gênesis, Deuteronômio, Êxodo, Oseias, Levíticos, 1Reis, Provérbios, Habacuque e Malaquias (PITTA, 2014, p. 28-29). Veja a Figura 1:

Figura 1: Uso do AT em Romanos

\begin{tabular}{|c|c|c|c|c|}
\hline & $\mathrm{NA}^{28} \mathrm{Rm} 1: 17-18^{6}$ & TH Hc 2:4b & Tradução NA28 & Análise \\
\hline 01 & 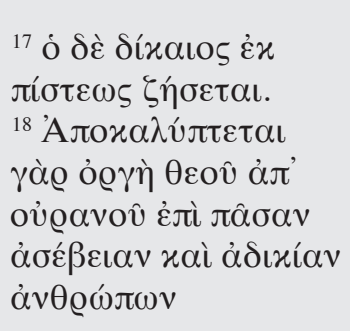 & וצדיק באמונתו יחיה & $\begin{array}{l}{ }^{17} \text { Mas o justo viverá da fé. } \\
{ }^{18} \text { Pois a ira de Deus é } \\
\text { revelada do céu contra } \\
\text { toda impiedade e injustiça } \\
\text { dos homens. }\end{array}$ & $\begin{array}{l}\text { v. } 17 \text { - Citação direta } \\
\text { do TH. } \\
\text { v. } 18 \text { apresenta ecos } \\
\text { inegáveis do AT. No } \\
\text { entanto, sem referências } \\
\text { específicas. Essa é uma } \\
\text { formulação exclusiva- } \\
\text { mente Paulina. }\end{array}$ \\
\hline
\end{tabular}

\footnotetext{
5 No cálculo apresentado por Hays (1989, p. 34), há uma diferença, computando 89 citações do AT nas cartas de Paulo, sendo 51 em Romanos. Apesar da incompatibilidade entre os números absolutos, a proporção se mantém: mais da metade das citações do AT nas cartas paulinas estão em Romanos.

${ }^{6}$ Novo Testamento Grego Nestle-Aland, $28^{\text {a }}$ edição.
} 


\begin{tabular}{|c|c|c|c|c|}
\hline \multirow{4}{*}{02} & $\mathrm{NA}^{28} \mathrm{Rm}$ 2:6 & LXX SI 60:13 & Tradução NA28 & Análise \\
\hline & \multirow{3}{*}{ 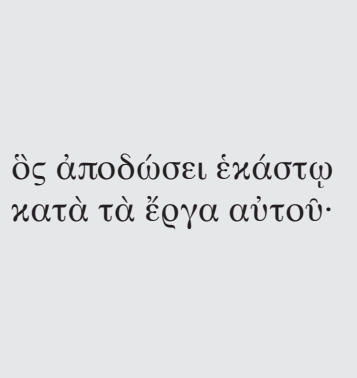 } & 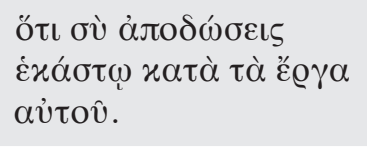 & \multirow{3}{*}{$\begin{array}{l}\text { Aquele que retribuirá a } \\
\text { cada um segundo a sua } \\
\text { obra. }\end{array}$} & \multirow{3}{*}{ Citação direta da LXX. } \\
\hline & & Pv 24:12 & & \\
\hline & & 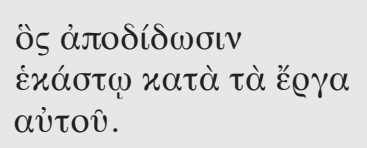 & & \\
\hline \multirow[b]{2}{*}{03} & $N^{28} \mathrm{Rm} 2: 24$ & LXX Is 52:5 & Tradução NA ${ }^{28}$ & Análise \\
\hline & 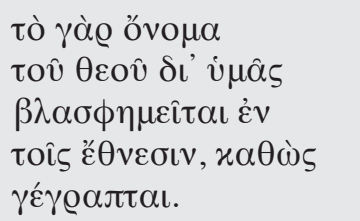 & 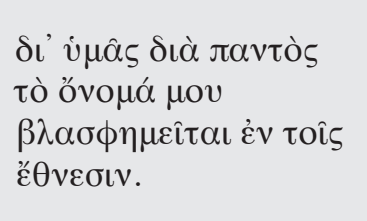 & $\begin{array}{l}\text { Assim, o nome de Deus } \\
\text { está sendo blasfemado } \\
\text { entre os gentios por meio } \\
\text { de vós, como está escrito. }\end{array}$ & Citação direta da LXX. \\
\hline \multirow[b]{2}{*}{04} & NA $^{28} \mathrm{Rm} 3: 4$ & LXX Is 50:6 & Tradução NA²8 & Análise \\
\hline & 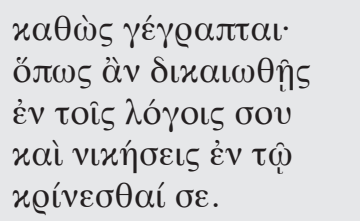 & 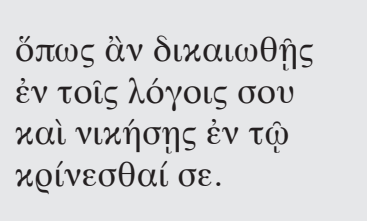 & $\begin{array}{l}\text { Como está escrito: para } \\
\text { que sejas justificado por } \\
\text { tuas palavras, e ganharás } \\
\text { a causa quando fores } \\
\text { julgado. }\end{array}$ & Citação direta da LXX. \\
\hline \multirow[b]{2}{*}{05} & NA $^{28} \mathrm{Rm} 3: 9$ & LXX Is 50:1 & Tradução NA 28 & Análise \\
\hline & 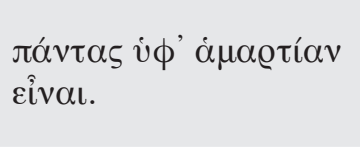 & 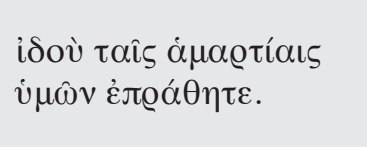 & $\begin{array}{l}\text { Todos estão debaixo do } \\
\text { pecado. }\end{array}$ & $\begin{array}{l}\text { Eco da LXX: "Eis que pe- } \\
\text { los vossos pecados fostes } \\
\text { vendidos." }\end{array}$ \\
\hline \multirow[b]{2}{*}{06} & $\mathrm{NA}^{28} \mathrm{Rm}$ 3:10-12 & LXX SI 13:1-3 & Tradução NA ${ }^{28}$ & Análise \\
\hline & 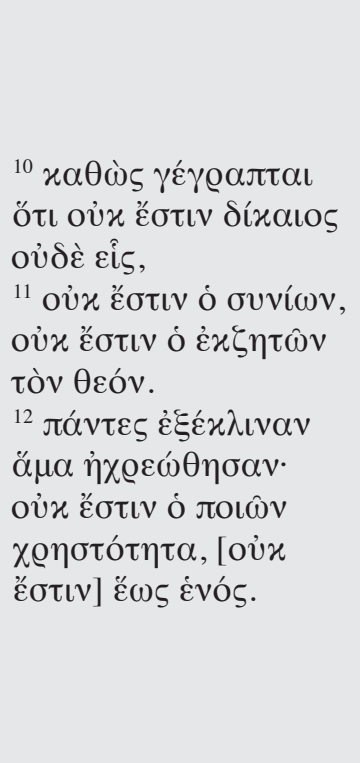 & 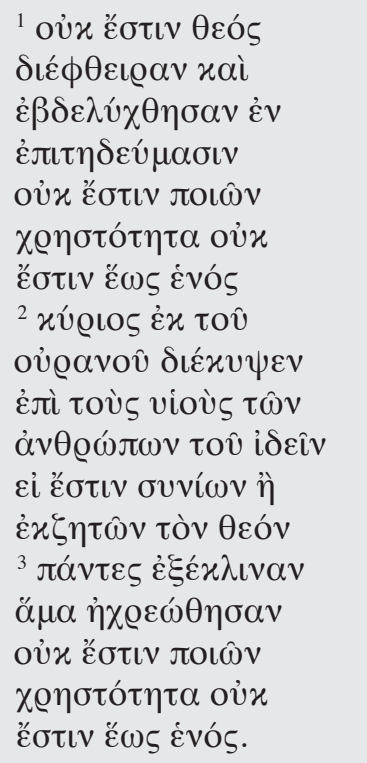 & $\begin{array}{l}{ }^{10} \text { Como está escrito que } \\
\text { não há um justo, nem um } \\
\text { sequer, } \\
{ }^{11} \text { não há quem entenda, } \\
\text { não há quem busque a } \\
\text { Deus; } \\
{ }^{12} \text { todos se desviaram, ao } \\
\text { mesmo tempo foram } \\
\text { tornados indignos; não há } \\
\text { quem pratique a bondade, } \\
\text { [não há] nem ao menos um. }\end{array}$ & $\begin{array}{l}\text { Citação direta da LXX e } \\
\text { eco de Ec 7:20: "... não há } \\
\text { um só homem justo sobre } \\
\text { a terra; e de 1Rs 8:46: } \\
\text { "pois não há homem que } \\
\text { não peque". }\end{array}$ \\
\hline
\end{tabular}




\begin{tabular}{|c|c|c|c|c|}
\hline & $\mathrm{NA}^{28} \mathrm{Rm}$ 3:13 & LXX SI 5:10 & Tradução NA²8 & Análise \\
\hline 07 & 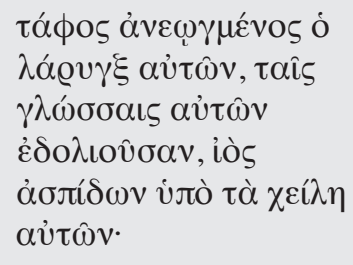 & 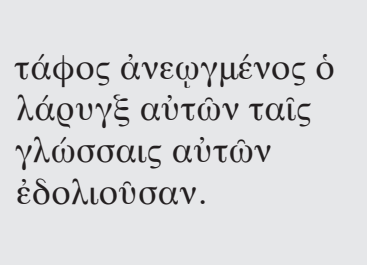 & $\begin{array}{l}\text { A garganta deles é um } \\
\text { sepulcro que foi aberto, } \\
\text { suas línguas passaram } \\
\text { a enganar, há veneno de } \\
\text { víboras sob seus lábios. }\end{array}$ & $\begin{array}{l}\text { Citação direta da LXX e } \\
\text { alusão ao SI 139:4 (SI } \\
\text { 140:4 TH). }\end{array}$ \\
\hline \multirow[b]{2}{*}{08} & $N^{28}{ }^{28}$ 3:14 & LXX SI 9:28 & Tradução NA ${ }^{28}$ & Análise \\
\hline & 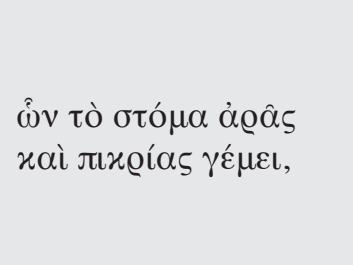 & 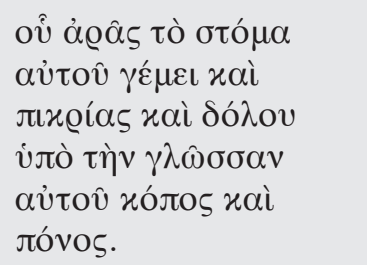 & $\begin{array}{l}\text { cuja boca está cheia de } \\
\text { maldição e amargura. }\end{array}$ & Citação da LXX.? \\
\hline \multirow[b]{2}{*}{09} & $N^{28} \mathrm{Rm}$ 3:15-17 & LXX Is 59:7-8 & Tradução NA ${ }^{28}$ & Análise \\
\hline & 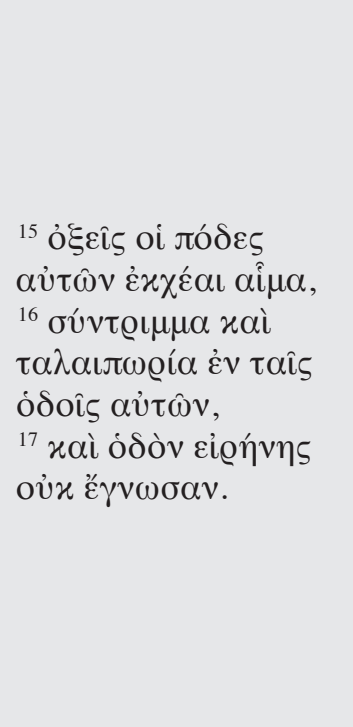 & 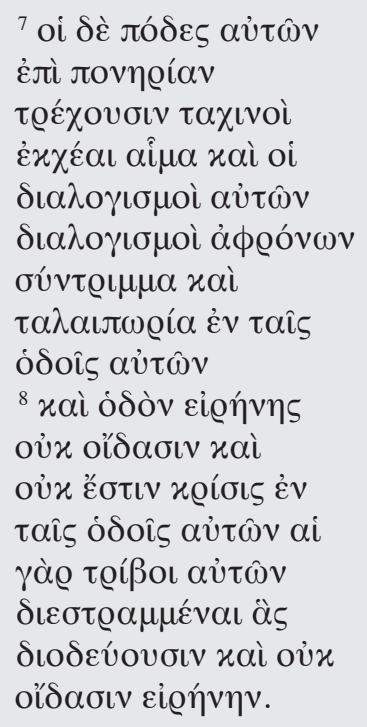 & $\begin{array}{l}{ }^{15} \text { seus pés são velozes } \\
\text { para derramar sangue, } \\
{ }^{16} \text { há ruína e miséria nos } \\
\text { caminhos deles, } \\
{ }^{17} \text { e não conheceram um } \\
\text { caminho de paz. }\end{array}$ & $\begin{array}{l}\text { Alusões, com algumas } \\
\text { diferenças da LXX. }\end{array}$ \\
\hline \multirow{4}{*}{10} & $\mathrm{NA}^{28} \mathrm{Rm}$ 3:18 & LXX SI 35:2 & Tradução NA ${ }^{28}$ & Análise \\
\hline & \multirow{3}{*}{ 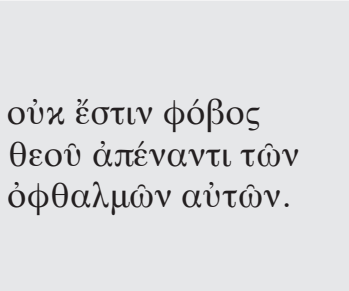 } & 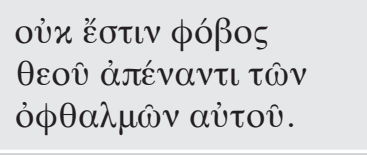 & \multirow{3}{*}{$\begin{array}{l}\text { Não há temor de Deus } \\
\text { diante de seus olhos. }\end{array}$} & \multirow{3}{*}{$\begin{array}{l}\text { Citação direta da LXX } \\
\text { do TH. }\end{array}$} \\
\hline & & TH SI 36:2 & & \\
\hline & & אין־פחד אלהים לנגד עיניו & & \\
\hline
\end{tabular}

${ }^{7}$ Convém observar que esta não é uma citação ipsis literis da LXX, o que é recorrente no epistolário paulino. Em sua obra Paul and the Language of Scripture, Stanley (1992, p. 51-53) propõe algumas possibilidades para se entender este fato. Segundo ele, uma possibilidade é que Paulo poderia estar se valendo de diferentes manuscritos da LXX, que continham algumas variantes diferentes, originadas pelos copitas. Outra é que, em alguns casos, Paulo estaria adaptando intencionamente a fraseologia do texto à sua audiência. Outra possibilidade que sugerimos ainda é a de que, em alguns casos, o apóstolo teria também feito citações de memória, que naturalmemte nem sempre equivalem a transcrições palavra por palavra, visto que a memória pode não se recordar de tudo ipsis literis. 


\section{Referências}

11

SI 106:20; Jr 2:11; 1 Sm 4:21; Is 42:25; 43:14-21; 44:22-

23; 48:20-21; 52:1; 53:12; 0s 2:14-23; Êx 25:17-22;

40:34-35; Lv 16:2-15; Am 9:1; 1Rs 8:6-11; Ez 11:23;

20:33-38; 43,1-5, 14-20; 44:4.

12

\section{Referências}

Gn 15-17.

\section{NA ${ }^{28} \mathrm{Rm}$ 4:3}

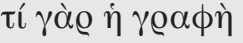

13

$\lambda \varepsilon ́ \gamma \varepsilon l ; \dot{\varepsilon} \pi i ́ \sigma \tau \varepsilon v \sigma \varepsilon v \delta \dot{\varepsilon}$

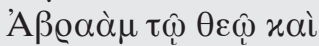

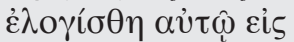

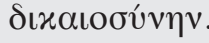

\section{$\mathrm{NA}^{28} \mathrm{Rm}$ 4:7-8}

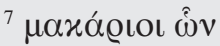

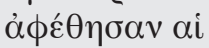

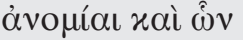

$14 \dot{\varepsilon} \pi \varepsilon \varkappa \alpha \lambda u ́ \phi \theta \eta \sigma \alpha v \alpha i$ $\dot{\alpha} \mu \alpha \varrho \tau i ́ \alpha l$.

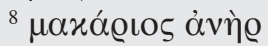

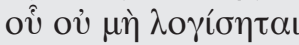

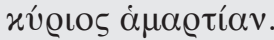

\section{Gn 15:6}

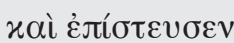

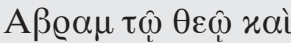

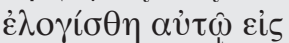

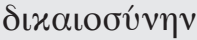

\begin{tabular}{|c|}
\hline LXX SI 31:1-2 \\
\hline 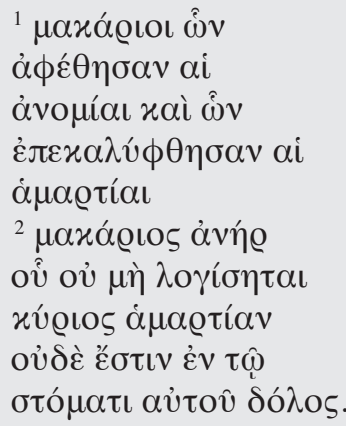 \\
\hline
\end{tabular}

\section{Análise Rm 3:21-26}

Não há citações explícitas ao AT, mas algumas alusões e ecos significativos.

\section{Análise $\mathrm{Rm}$ 4,1-25}

Alusões a Gn 15-17.

\section{Tradução NA ${ }^{28}$}

Pois o que diz a Escritura? Abraão creu em Deus, e isto Ihe foi imputado para justiça.

\section{Análise}

Citação direta da LXX. Segundo Penna $(2013$, p. 66), aqui temos um midrash de Abraão.

\section{Referências}

Paulo faz alusões aos personagens do AT, tais como Abraão, Moisés e Adão. Também faz alusões a temas teológicos como desobediência, transgressão, graça, justiça e justificação.

\section{Tradução NA ${ }^{28}$}

${ }^{7}$ Bem-aventurados são aqueles cujas iniquidades foram perdoadas e cujos pecados foram cobertos; ${ }^{8}$ bem-aventurado é 0 homem ao qual o Senhor nunca atribui pecado.

\section{Análise}

Citação direta da LXX.

\section{Análise $\mathrm{Rm}$ 4:9-6:23}

Alusões e ecos do AT, mas sem citação explicita de alguma parte das Escrituras. Aliás, segundo Moo (2014, p. 55-58) essa epístola traz uma riqueza muito grande no que tange aos temas paulinos.

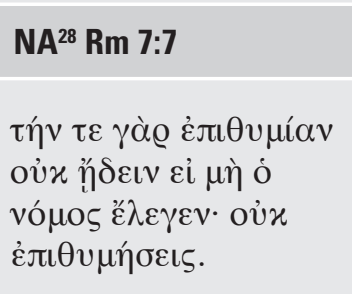

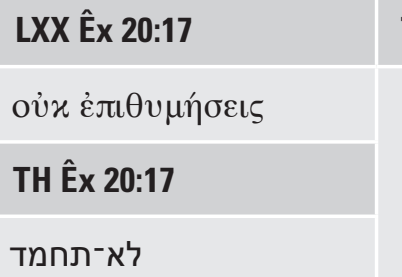

\section{Tradução NA ${ }^{28}$}

pois não teria eu conhecido a cobiça, se a lei não tivesse dito: Não cobiçarás.

\begin{tabular}{|c|}
\hline yy \\
\hline 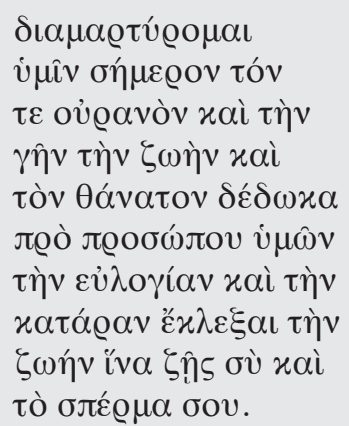 \\
\hline
\end{tabular}

\section{Tradução NA ${ }^{28}$ \\ ${ }^{11}$ Pois quando o pecado encontrou uma oportuni- dade através do man- damento, enganou-me completamente, e através do mandamento me matou. \\ ${ }^{12}$ Portanto, a lei é santa; e o mandamento é santo, e justo, e bom.}

\section{Análise}

Citação direta da LXX e do TH ao texto de Êxx 20:17 e de Dt 5:21.

\section{Análise}

Alusões a Dt 30:15-20; Gn 2:17; 3:3; Êx 20:4-5; 20:19-21; Lv 18:5. 


\begin{tabular}{|c|c|c|c|c|}
\hline \multirow[b]{2}{*}{18} & $\mathrm{NA}^{28} \mathrm{Rm} \mathbf{8 , 3 1 b}$ & LXX Referências & Tradução NA ${ }^{28}$ & Análise \\
\hline & 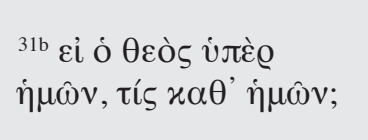 & $\begin{array}{l}\text { Is 41:11-24; 43-46; } \\
\text { 50:8-9; 51:3-8; SI 109:1-3; } \\
\text { 117:5-9; e SI 138:7-12. }\end{array}$ & $\begin{array}{l}{ }^{31} \text { Se Deus está a nosso } \\
\text { favor, quem está contra } \\
\text { nós? }\end{array}$ & Ecos da LXX e do TH. \\
\hline \multirow[b]{2}{*}{19} & $N^{28} \operatorname{Rm} 8: 32 a-b$ & LXX Referências & Tradução NA ${ }^{28}$ & Análise \\
\hline & 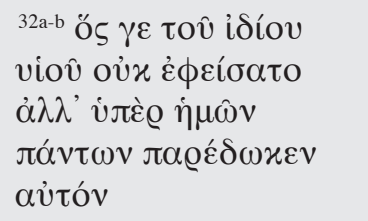 & Gn 22:7-16; Is 53 & $\begin{array}{l}\text { 32a-b Aquele que não } \\
\text { poupou o seu próprio } \\
\text { Filho, antes, o entregou } \\
\text { em lugar de todos nós. }\end{array}$ & Ecos da LXX e do TH. \\
\hline \multirow[b]{2}{*}{20} & $\mathrm{NA}^{28} \mathrm{Rm}$ 8:36 & LXX SI 43:23 & Tradução NA 28 & Análise \\
\hline & 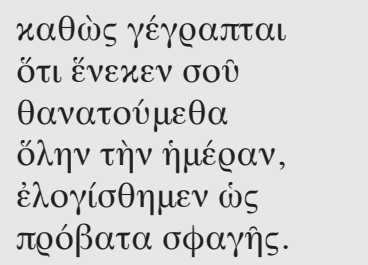 & 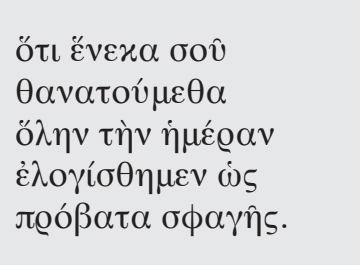 & $\begin{array}{l}\text { Como está escrito: Por } \\
\text { tua causa, somos deixa- } \\
\text { dos à morte o dia todo, } \\
\text { fomos considerados como } \\
\text { ovelhas do matadouro. }\end{array}$ & $\begin{array}{l}\text { Citação direta da LXX } \\
\text { e alusões a Gn 22:7-8; } \\
\text { SI 25:5; 38:6; 43:21-27; } \\
\text { 73:14; 74:22; 86:3; 102:8; } \\
\text { Is 43:7. }\end{array}$ \\
\hline \multirow[b]{2}{*}{21} & \multicolumn{2}{|l|}{ LXX Referências } & \multicolumn{2}{|l|}{ Análise Rm 9:1-11 } \\
\hline & \multicolumn{2}{|c|}{$\begin{array}{l}\text { Referências aos ciclos de histórias dos patriarcas } \\
\text { Abraão, Isaque e Jacó (Gn 12-35; 49:8-12). }\end{array}$} & \multicolumn{2}{|c|}{ Ecos das alianças que Deus fez com os patriarcas. } \\
\hline \multirow[b]{2}{*}{22} & $\mathrm{NA}^{28} \mathrm{Rm}$ 9:7b & LXX Gn 21:12 & Tradução NA 28 & Análise \\
\hline & 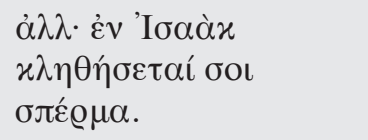 & 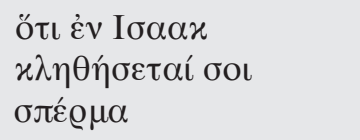 & $\begin{array}{l}\text { mas em Isaque será cha- } \\
\text { mada a tua descendência. }\end{array}$ & Citação direta da LXX. \\
\hline \multirow[b]{2}{*}{23} & $\mathrm{NA}^{28} \mathrm{Rm}$ 9:9 & LXX Gn 18:10 & Tradução NA ${ }^{28}$ & Análise \\
\hline & 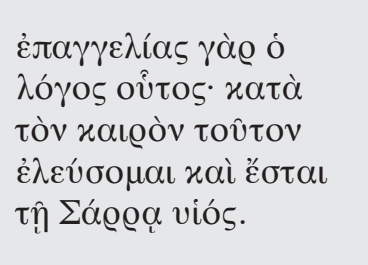 & 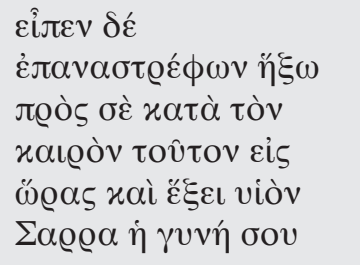 & $\begin{array}{l}\text { Pois esta é a palavra } \\
\text { da promessa: por esse } \\
\text { tempo virei, e Sara terá } \\
\text { um filho. }\end{array}$ & Citação direta da LXX. \\
\hline \multirow[b]{2}{*}{24} & $N^{28} \operatorname{Rm} 9: 10-11$ & LXX/TH Referências & Tradução NA 28 & Análise \\
\hline & 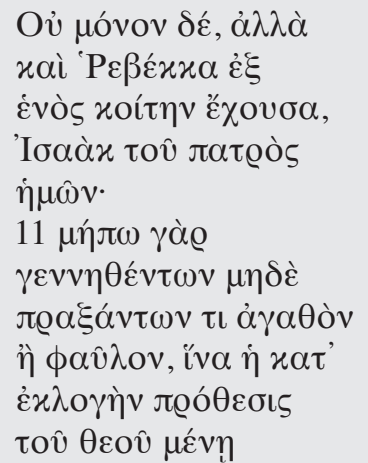 & Gn 25:20-26 & $\begin{array}{l}\text { E não ela somente, mas } \\
\text { também Rebeca, ao con- } \\
\text { ceber de um só, Isaque, } \\
\text { nosso pai. E ainda não } \\
\text { eram os gêmeos nascidos, } \\
\text { nem tinham praticado o } \\
\text { bem ou o mal }\end{array}$ & $\begin{array}{l}\text { Alusão à história de Isa- } \\
\text { que, Rebeca e seus filhos } \\
\text { gêmeos, como consta na } \\
\text { LXX e no TH. }\end{array}$ \\
\hline
\end{tabular}




\begin{tabular}{|c|c|c|c|c|}
\hline \multirow[b]{2}{*}{25} & $N^{28} \operatorname{Rm} 9: 12$ & LXX Gn 25:23 & Tradução NA²8 & Análise \\
\hline & 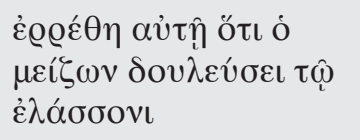 & 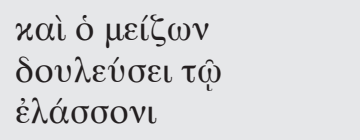 & $\begin{array}{l}\text { foi dito a ela que o mais } \\
\text { velho servirá ao mais } \\
\text { novo }\end{array}$ & Citação direta da LXX. \\
\hline \multirow[b]{2}{*}{26} & $N^{28} \operatorname{Rm} 9: 13$ & LXX MI 1:2b-3a & Tradução NA ${ }^{28}$ & Análise \\
\hline & 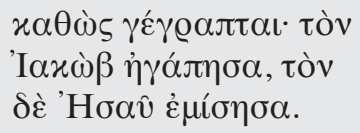 & 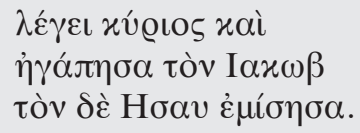 & $\begin{array}{l}\text { Como está escrito: Valo- } \\
\text { rizei Jacó e não escolhi } \\
\text { Esaú. }\end{array}$ & Citação direta da LXX. \\
\hline \multirow[b]{2}{*}{27} & $N^{28} \operatorname{Rm} 9: 15$ & LXX Êx 33:19 & Tradução NA ${ }^{28}$ & Análise \\
\hline & 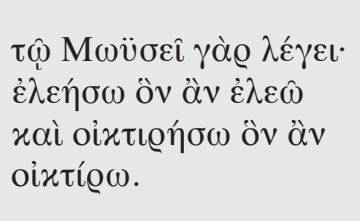 & 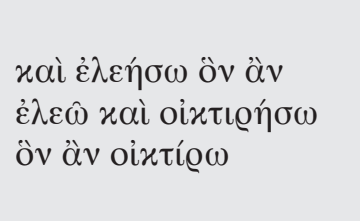 & $\begin{array}{l}\text { Pois ele diz a Moisés: Te- } \\
\text { rei misericórdia de quem } \\
\text { eu tiver misericórdia e } \\
\text { terei compaixão de quem } \\
\text { eu tiver compaixão. }\end{array}$ & Citação direta da LXX. \\
\hline \multirow[b]{2}{*}{28} & $N^{28} \operatorname{Rm} 9: 17$ & LXX Êx 9:16 & Tradução NA ${ }^{28}$ & Análise \\
\hline & 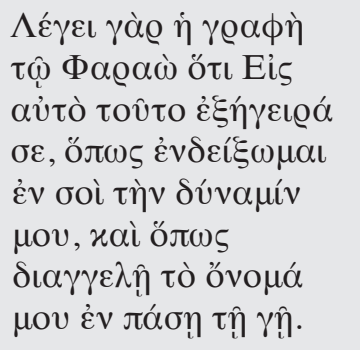 & 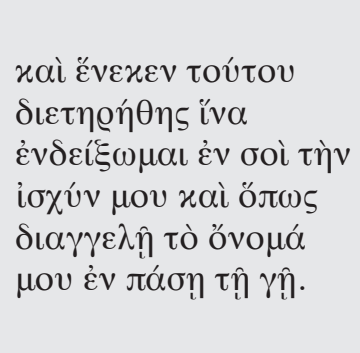 & $\begin{array}{l}\text { Porque a Escritura diz a } \\
\text { Faraó: Para isto mesmo } \\
\text { te levantei, para que eu } \\
\text { mostrasse em ti o meu } \\
\text { poder e para que o meu } \\
\text { nome se tornasse conhe- } \\
\text { cido em toda a terra. }\end{array}$ & Citação direta da LXX. \\
\hline \multirow[b]{2}{*}{29} & $N^{28} \operatorname{Rm} 9: 18$ & LXX Êx 9:12 & Tradução NA & Análise \\
\hline & 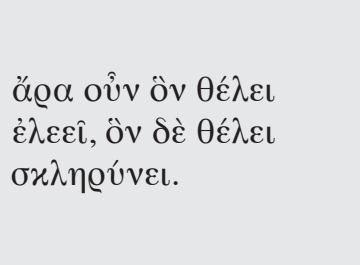 & 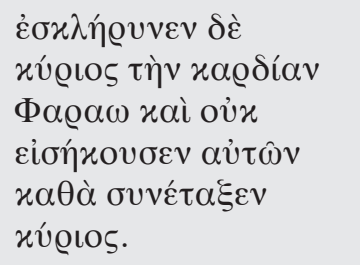 & $\begin{array}{l}\text { Portanto, Deus tem } \\
\text { misericórdia de quem ele } \\
\text { quer e endurece a quem } \\
\text { ele quer. }\end{array}$ & Alusão à LXX. \\
\hline \multirow[b]{2}{*}{30} & $N^{28} \mathrm{Rm}$ 9:21 & LXX Is 29:16 & Tradução NA ${ }^{28}$ & Análise \\
\hline & 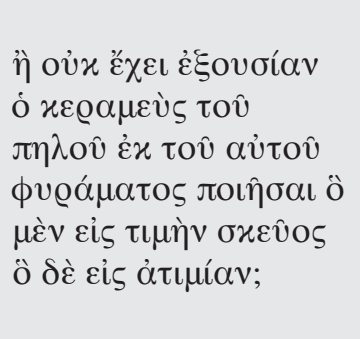 & 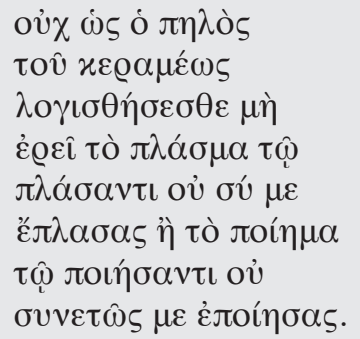 & $\begin{array}{l}\text { Ou o oleiro não tem } \\
\text { domínio do barro, para } \\
\text { da sua massa extrair um } \\
\text { vaso para honra e outro } \\
\text { para desonra? }\end{array}$ & $\begin{array}{l}\text { Alusão à LXX e a Êx 9:22; } \\
\text { Is 45:9 e Jr 18:1-2 na LXX } \\
\text { e no TH. }\end{array}$ \\
\hline
\end{tabular}




\begin{tabular}{|c|c|c|c|c|}
\hline & NA $^{28} \mathrm{Rm}$ 9:25-26 & LXX Os 2:25; 2:1 & Tradução NA²8 & Análise \\
\hline 31 & 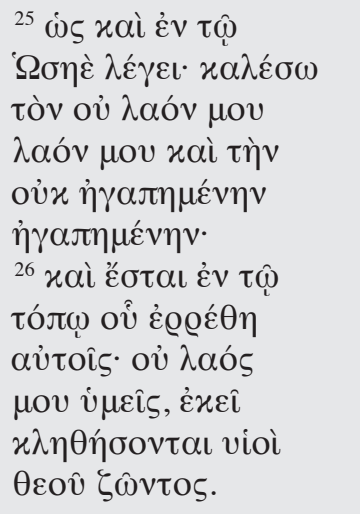 & 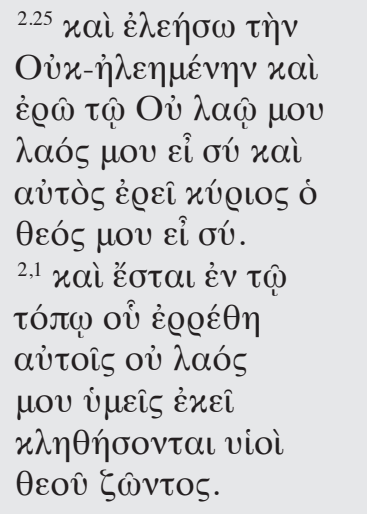 & $\begin{array}{l}{ }^{25} \text { Assim como também } \\
\text { diz em Oseias: Chamarei } \\
\text { meu povo ao que não era } \\
\text { meu povo; e amada, à } \\
\text { que não era amada. } \\
{ }^{26} \text { e no lugar em que se } \\
\text { lhes disse: Vós não sois } \\
\text { meu povo, ali mesmo } \\
\text { serão chamados filhos do } \\
\text { Deus vivo. }\end{array}$ & $\begin{array}{l}\text { Rm 9:25 faz alusão a Os } \\
\text { 2:25 e 10:1 na LXX e no } \\
\text { TH. } \\
\text { Rm 9:26 faz citação direta } \\
\text { de 0s 2:1 da LXX. }\end{array}$ \\
\hline & NA $^{28} \mathrm{Rm}$ 9:27-28 & LXX Is 10:22-23 & Tradução NA ${ }^{28}$ & Análise \\
\hline 32 & 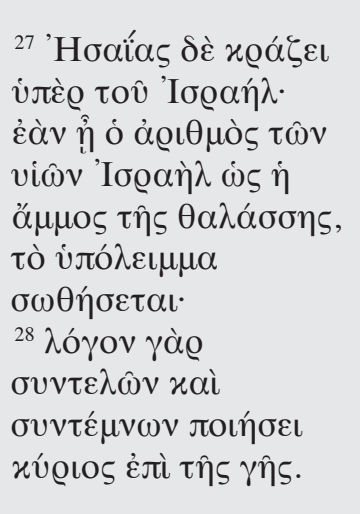 & 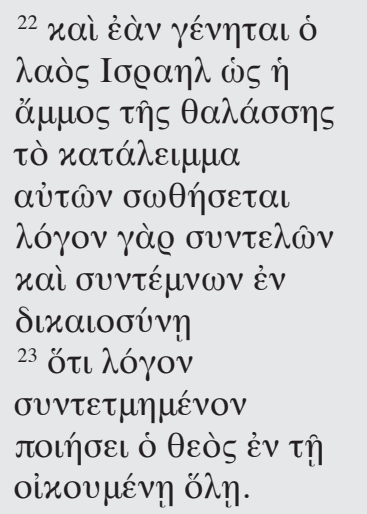 & $\begin{array}{l}{ }^{27} \text { Mas, com relação a Is- } \\
\text { rael, Isaías clama: Ainda } \\
\text { que o número dos filhos } \\
\text { de Israel seja como a } \\
\text { areia do mar, o remanes- } \\
\text { cente será salvo; } \\
{ }^{28} \text { Pois o Senhor cumprirá } \\
\text { completamente e em } \\
\text { breve a palavra sobre a } \\
\text { terra. }\end{array}$ & $\begin{array}{l}\text { Citação interpretativa, } \\
\text { com variações da LXX e } \\
\text { do TH. }\end{array}$ \\
\hline & $N^{28} \operatorname{Rm} 9: 29$ & LXX Is 1:9 & Tradução NA²8 & Análise \\
\hline 33 & 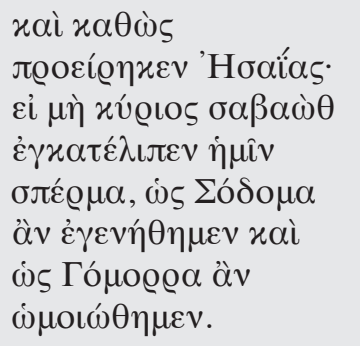 & 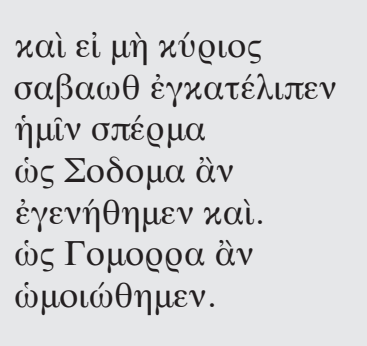 & $\begin{array}{l}\text { Como Isaías predisse: Se } \\
\text { o Senhor dos Exércitos } \\
\text { não deixsse uma descen- } \\
\text { dência para nós, seríamos } \\
\text { feitos como Sodoma e } \\
\text { tornados semelhantes a } \\
\text { Gomorra. }\end{array}$ & $\begin{array}{l}\text { Citação direta da LXX e } \\
\text { alusão a Gn } 19 .\end{array}$ \\
\hline & $\mathrm{NA}^{28} \mathrm{Rm}$ 9:33 & LXX Is 28:16 & Tradução NA ${ }^{28}$ & Análise \\
\hline 34 & 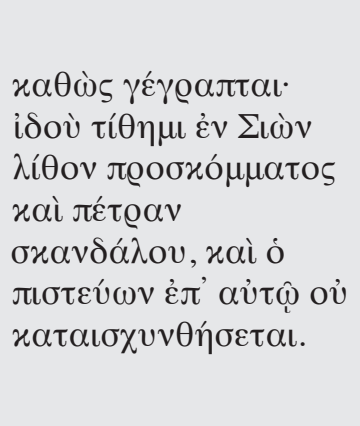 & 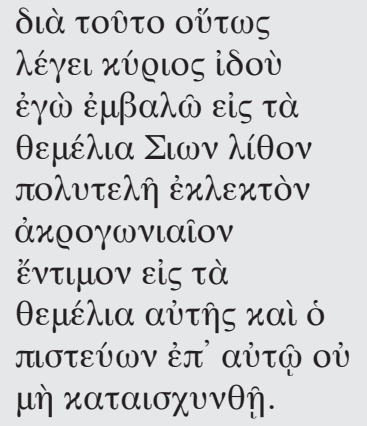 & $\begin{array}{l}\text { como está escrito: Eis } \\
\text { que ponho em Sião uma } \\
\text { pedra de tropeço e rocha } \\
\text { de escândalo, e aquele } \\
\text { que nela crê não será } \\
\text { envergonhado. }\end{array}$ & $\begin{array}{l}\text { Citação da LXX de Is } \\
28: 16 \text { e alusão a Is 8:14. }\end{array}$ \\
\hline
\end{tabular}




\begin{tabular}{|c|c|c|c|c|}
\hline \multirow[b]{2}{*}{35} & $\mathrm{NA}^{28} \mathrm{Rm}$ 10:5 & LXX/TH Lv 18:4 & Tradução NA28 & Análise \\
\hline & 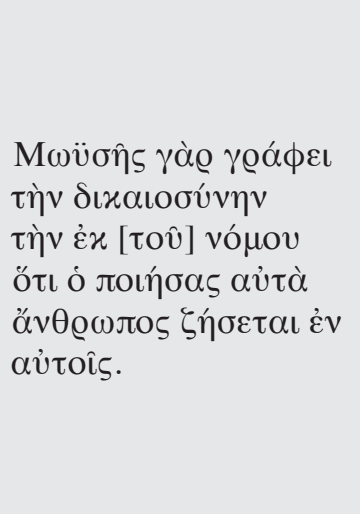 & 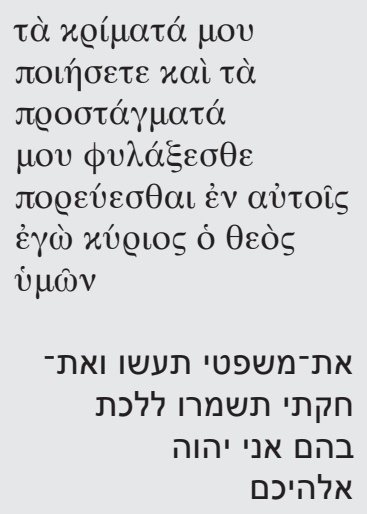 & $\begin{array}{l}\text { Pois Moisés escreveu } \\
\text { sobre a justiça da lei que } \\
\text { o homem que fizer estas } \\
\text { coisas, viverá por elas. }\end{array}$ & $\begin{array}{l}\text { Alusão a Lv 18:4 na LXX } \\
\text { e no TH. }\end{array}$ \\
\hline \multirow[b]{2}{*}{36} & $\mathrm{NA}^{28} \mathrm{Rm} 10,6-8$ & LXX Dt 30:11-14 & Tradução NA ${ }^{28}$ & Análise \\
\hline & 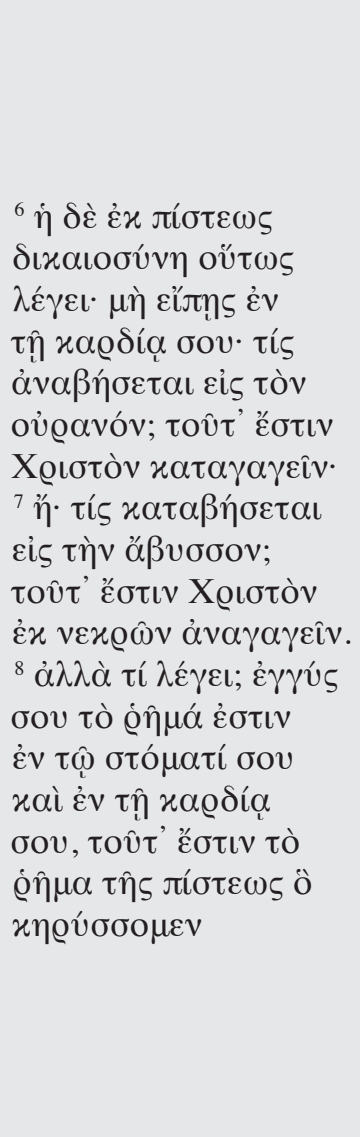 & 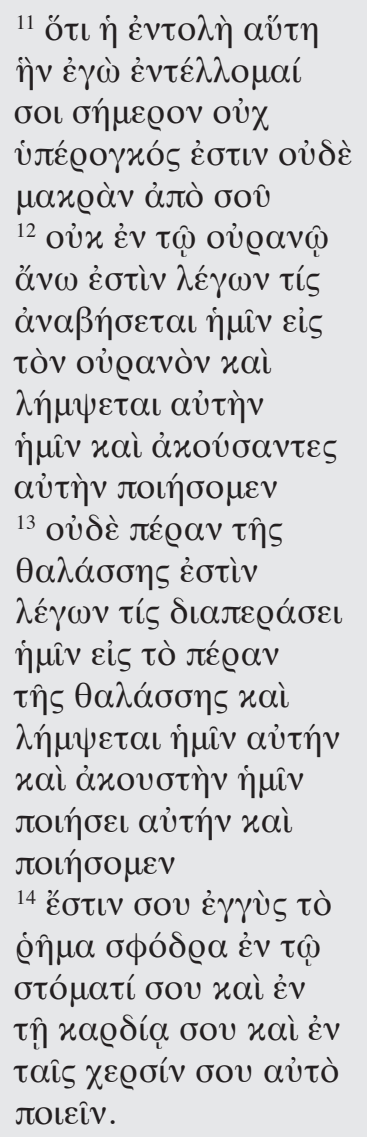 & $\begin{array}{l}{ }^{6} \text { Mas a justiça da fé diz } \\
\text { assim: Não perguntes no } \\
\text { teu coração: Quem se ele- } \\
\text { vará ao céu? Isto é, para } \\
\text { trazer do alto a Cristo; } \\
{ }^{7} \text { ou: Quem descerá ao } \\
\text { abismo? Isto é, para } \\
\text { levantar Cristo dentre os } \\
\text { mortos. } \\
{ }^{8} \text { Mas, o que ele diz? A } \\
\text { palavra está perto de } \\
\text { ti, na tua boca e no teu } \\
\text { coração; isto é, a palavra } \\
\text { da fé que proclamamos. }\end{array}$ & $\begin{array}{l}\text { Alusão à LXX. Para alguns } \\
\text { estudiosos, essa forma de } \\
\text { citação sugere um tipo de } \\
\text { interpretação encontrada } \\
\text { num pesher de Qumram. } \\
\text { (SEIFRID, 2014, p. 816). } \\
\text { Para outros, Paulo } \\
\text { poderia estar recorrendo } \\
\text { a uma tradição targúmica } \\
\text { de Dt 10,12-14 nesta } \\
\text { passagem (SILVA, 2008, } \\
\text { p. 83). }\end{array}$ \\
\hline \multirow[b]{2}{*}{37} & $\mathrm{NA}^{28} \mathrm{Rm} 10,11$ & LXX Is 28:16 & Tradução NA & Análise \\
\hline & 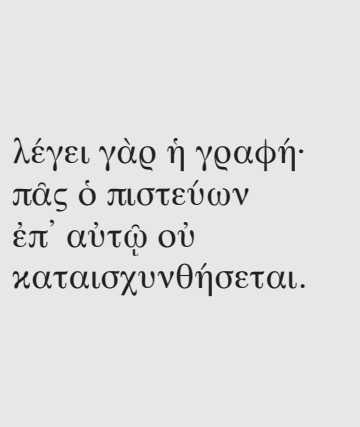 & 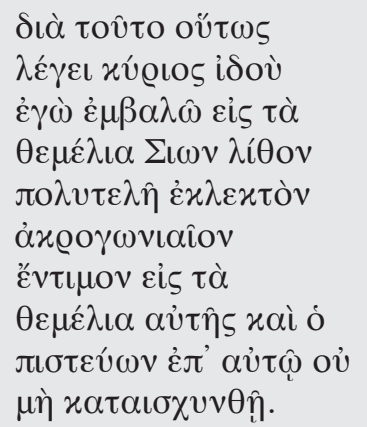 & $\begin{array}{l}\text { Porquanto a Escritura diz: } \\
\text { Todo aquele que nele crê } \\
\text { não será envergonhado. }\end{array}$ & $\begin{array}{l}\text { Citação direta da LXX } \\
\text { e alusão a Jl 2:32 e Dt } \\
\text { 30:14. }\end{array}$ \\
\hline
\end{tabular}




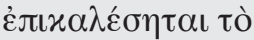
övo $\mu \alpha$ xv@íov $\sigma \omega \theta \eta \dot{\sigma \varepsilon \tau \alpha \text {. }}$

\section{$N^{28} \mathrm{Rm} 10: 15 c$}

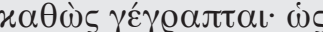

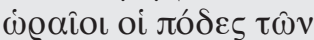

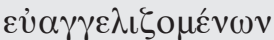
$[\tau \grave{\alpha}] \dot{\alpha} \gamma \alpha \theta \alpha$.

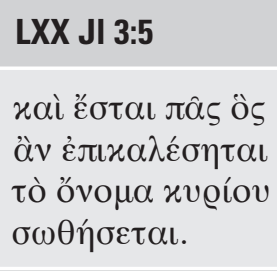

\section{Is 52:7}

ஸ்

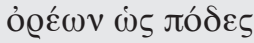

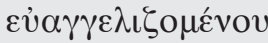

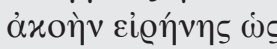

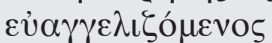

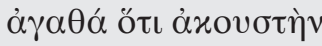

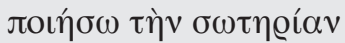
бov $\lambda \varepsilon \dot{\varepsilon} \gamma \omega v \Sigma \mathrm{\iota} \omega v$ $\beta \alpha \sigma \iota \lambda \varepsilon v ́ \sigma \varepsilon \iota$ бov ó $\theta \varepsilon o ́ s$.

\section{NA $^{28} \mathrm{Rm}$ 10:16}

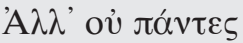

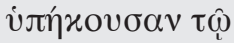

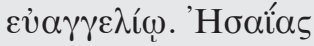

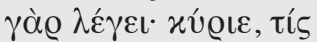

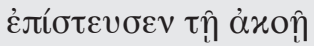
$\dot{\eta} \mu \omega \mathrm{v}$

\section{Tradução NA ${ }^{28}$}

Pois todo aquele que invocar o nome do Senhor será salvo.

\section{Tradução NA ${ }^{28}$}

Como está escrito: Quão formosos são os pés dos que anunciam coisas boas!

\section{Análise}

Citação direta da LXX.

\section{Análise}

Alusões à LXX de Is 52:7; 40:9 e eco de Na 1:15.

\section{Is 53:1}

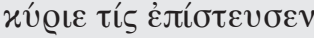

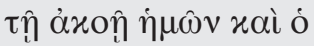

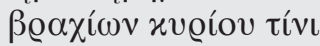

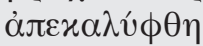

\section{Tradução NA28 \\ Análise}

Mas nem todos obedeceram ao Evangelho. Isaías, pois, diz: Senhor, quem deu crédito à nossa pregação?

\section{Tradução NA ${ }^{28}$}

Mas pergunto: Não ouviram? Ao contrário: A voz deles se expande por toda a terra, e as suas palavras, até aos confins do mundo.

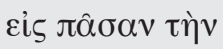

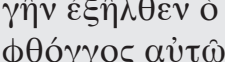

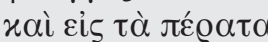

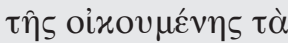

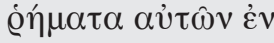

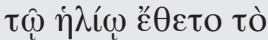

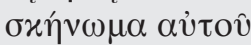

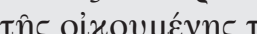

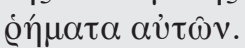

\section{Dt 32:21}

$\alpha$

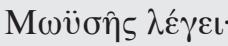

42

$\varepsilon \gamma \omega \pi \alpha \varrho \alpha \zeta \eta \lambda \omega \sigma \omega$

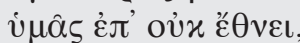

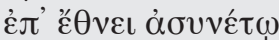

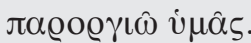

$\mu \varepsilon \dot{\varepsilon} \pi$ ' ở $\theta \varepsilon \hat{\omega}$

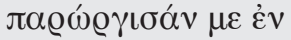

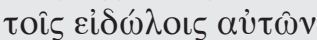

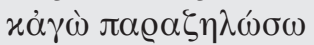

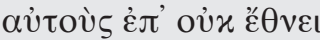

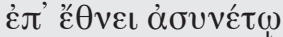

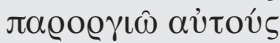

\section{Tradução NA ${ }^{28}$}

Moisés diz: Eu vos provocarei ciúmes com uma que não é nação, com uma nação sem entendimento vos provocarei ciúmes.
Citação direta da LXX.

Citação direta da LXX.

Citação direta da LXX. 


\begin{tabular}{|c|c|c|c|c|}
\hline \multirow[b]{2}{*}{43} & $N^{28} \operatorname{Rm} 10: 20-21$ & LXX Is 65:1-2 & Tradução NA28 & Análise \\
\hline & 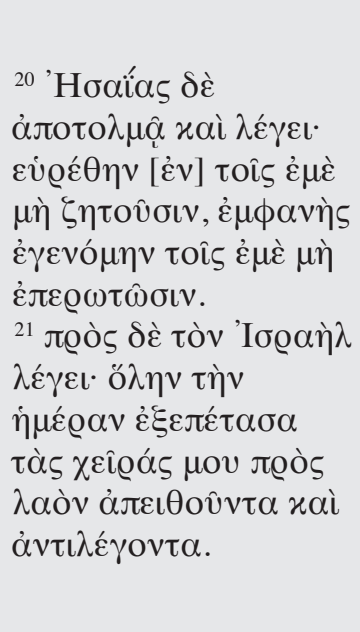 & 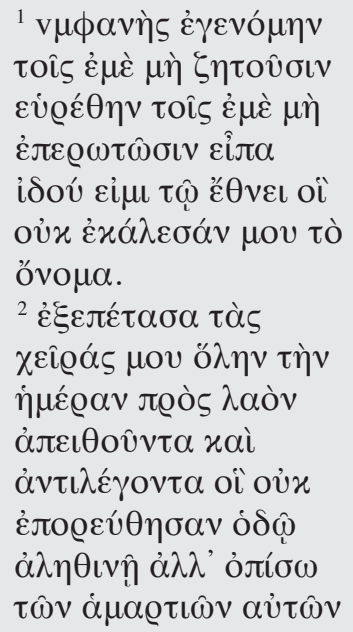 & $\begin{array}{l}{ }^{20} \text { E Isaías a mais se atre- } \\
\text { ve e diz: Fui achado pelos } \\
\text { que não me procuravam, } \\
\text { revelei-me aos que não } \\
\text { perguntavam por mim. } \\
{ }^{21} \text { Quanto a Israel, porém } \\
\text { diz: Todo o dia estendi as } \\
\text { mãos a um povo rebelde } \\
\text { e contradizente. }\end{array}$ & Citação direta da LXX. \\
\hline \multirow{4}{*}{44} & $\mathrm{NA}^{28} \mathrm{Rm}$ 11:8 & LXX Is 29:10 & Tradução NA 28 & Análise \\
\hline & \multirow{3}{*}{ 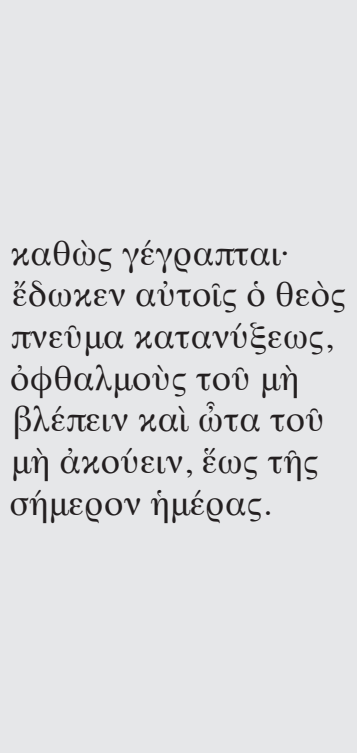 } & 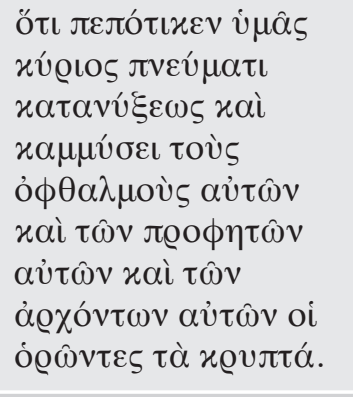 & \multirow{3}{*}{$\begin{array}{l}\text { Como está escrito: Deus } \\
\text { deu a eles um espírito de } \\
\text { entorpecimento, olhos } \\
\text { para não ver e ouvidos } \\
\text { para não ouvir, até o dia } \\
\text { de hoje. }\end{array}$} & \multirow{3}{*}{$\begin{array}{l}\text { Referência mista à LXX. } \\
\text { Alusão a Is 6:9-13; Dt } \\
\text { 9:24. }\end{array}$} \\
\hline & & Dt 29:3 & & \\
\hline & & 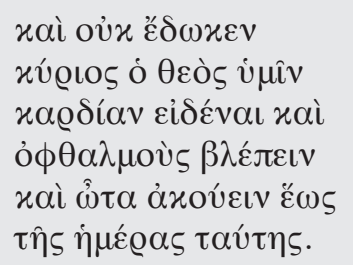 & & \\
\hline & $\mathrm{NA}^{28} \mathrm{Rm}$ 11:9-10 & LXX SI 68:24-25 & Tradução NA ${ }^{28}$ & Análise \\
\hline 46 & 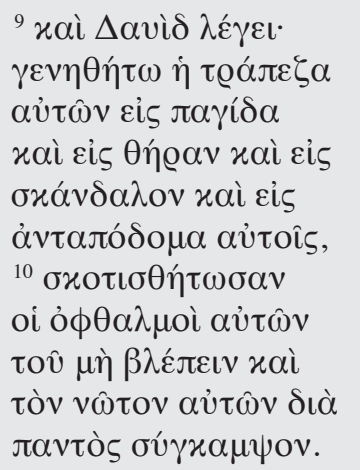 & 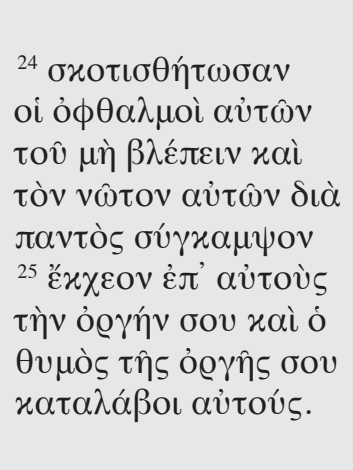 & $\begin{array}{l}{ }^{9} \text { E Davi diz: Seja trans- } \\
\text { formada a mesa deles } \\
\text { em laço e armadilha, } \\
\text { em motivo de tropeço e } \\
\text { retribuição; } \\
{ }^{10} \text { seus olhos sejam } \\
\text { escurecidos para não ver, } \\
\text { e encurvai as suas costas } \\
\text { para sempre. }\end{array}$ & $\begin{array}{l}\text { Citação direta da LXX. } \\
\text { Alusões a 2Sm 22:40; SI } \\
\text { 38:6 [37:7 LXX]; 57:5 [56:7 } \\
\text { LXX]; 68:10-W23; v. tb. } \\
\text { Gn 49:8; SI 66:11 [65:11 } \\
\text { LXX]; 81:6 [80:7 LXX]; } \\
\text { 129:3 [128:3 LXX]. }\end{array}$ \\
\hline
\end{tabular}




\begin{tabular}{|c|c|c|c|c|}
\hline & $\mathrm{NA}^{28} \mathrm{Rm} 11: 23-24$ & LXX Referências & Tradução NA²8 & Análise \\
\hline 47 & 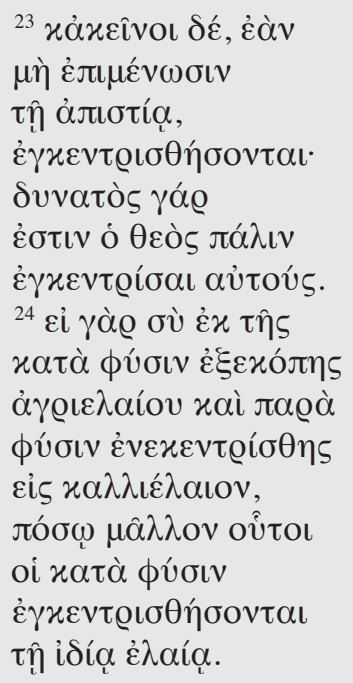 & $\begin{array}{l}\text { Is } 2: 2-5 ; 11: 10 ; 26: 2 ; \\
30: 29 ; 59: 20 ; \text { Mq 4:1-4. }\end{array}$ & $\begin{array}{l}{ }^{23} \text { E aqueles, se não per- } \\
\text { manecerem na increduli- } \\
\text { dade, serão enxertados; } \\
\text { pois Deus é poderoso } \\
\text { para os enxertar de novo. } \\
{ }^{24} \text { Pois, se foste cortado } \\
\text { da que, por natureza, era } \\
\text { oliveira silvestre, e contra } \\
\text { a natureza, enxertado na } \\
\text { oliveira cultivada, quanto } \\
\text { mais serão enxertados } \\
\text { na sua própria oliveira } \\
\text { aqueles que são galhos } \\
\text { naturais! }\end{array}$ & Alusões à LXX. \\
\hline \multirow{4}{*}{48} & NA $^{28} \mathrm{Rm}$ 11:26-27 & LXX Is 59:20-21 & Tradução NA & Análise \\
\hline & \multirow[t]{3}{*}{ 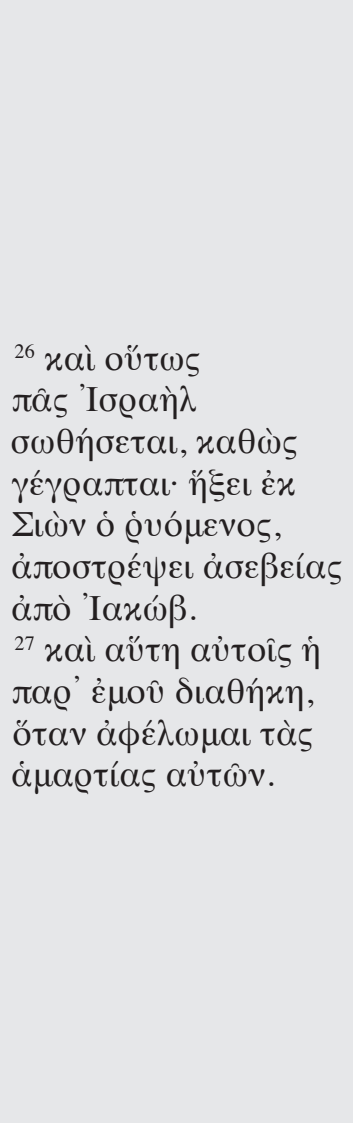 } & 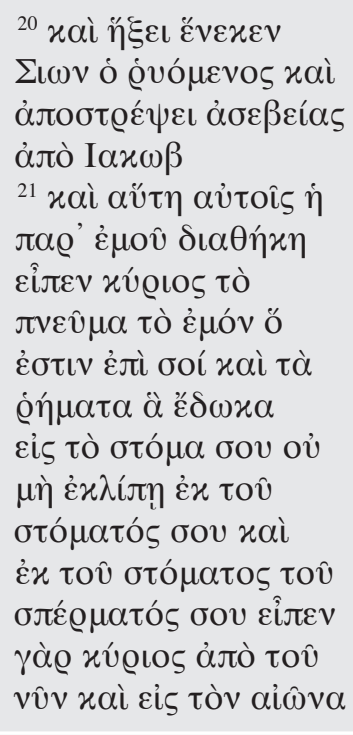 & \multirow[t]{3}{*}{$\begin{array}{l}{ }^{26} \text { E, assim, todo o Israel } \\
\text { será salvo, como está } \\
\text { escrito: } 0 \text { Libertador virá } \\
\text { de Sião e afastará as } \\
\text { impiedades de Jacó. } \\
{ }^{27} \text { Esta será a minha alian- } \\
\text { ça com eles, quando eu } \\
\text { retirar os seus pecados. }\end{array}$} & \multirow[t]{3}{*}{$\begin{array}{l}\text { Em alusão à Escritura, } \\
\text { Israel é visto aqui como } \\
\text { uma realidade coletiva } \\
\text { (e.g., Dt } 1,1 ; 5,1 ; 29,2 ; \\
31,11 ; \text { Js } 3,7 ; 1 \mathrm{Sm} 7,5) \\
\text { Paulo extrai a primeira } \\
\text { parte de sua referência } \\
\text { de Is } 59,20-21 \text { da LXX } \\
\text { e a última parte, de Is } \\
27,9 \text { LXX. Entretanto, a } \\
\text { formulação é paulina. }\end{array}$} \\
\hline & & Is $27: 9$ & & \\
\hline & & 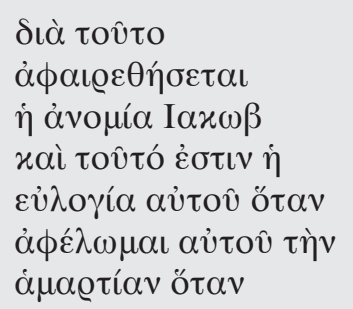 & & \\
\hline
\end{tabular}




\begin{tabular}{|c|c|c|c|c|}
\hline \multirow[b]{3}{*}{49} & NA $^{28} \mathrm{Rm}$ 11:33-35 & LXX Is 40:13 & Tradução NA²8 & Análise \\
\hline & \multirow{2}{*}{ 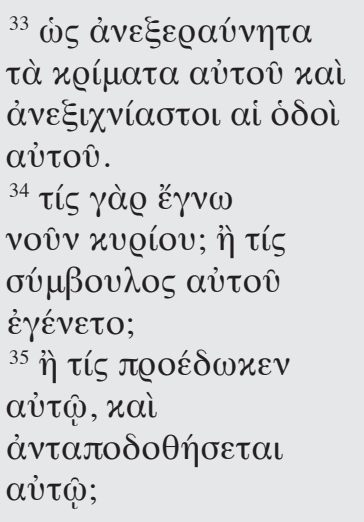 } & 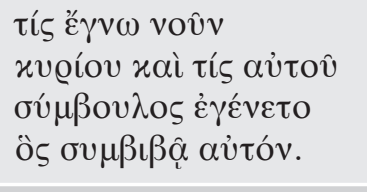 & \multirow{2}{*}{$\begin{array}{l}{ }^{33} \text { Quão insondáveis são } \\
\text { os seus juízos, e quão } \\
\text { inescrutáveis são os seus } \\
\text { caminhos! } \\
{ }^{34} \text { Pois quem conheceu } \\
\text { a mente do Senhor? Ou } \\
\text { quem foi feito seu conse- } \\
\text { Iheiro? } \\
{ }^{35} \text { Ou quem deu primeiro } \\
\text { a ele, e será recompen- } \\
\text { sado? }\end{array}$} & \multirow[b]{2}{*}{$\begin{array}{l}\text { Citação direta da LXX em } \\
\text { Is 40:13 e alusão ao TH } \\
\text { em Jó 41:3. }\end{array}$} \\
\hline & & מי הקדימני ואשלם & & \\
\hline & $N^{28} \operatorname{Rm} 12: 1-2$ & LXX Referências & Tradução NA ${ }^{28}$ & Análise \\
\hline 50 & 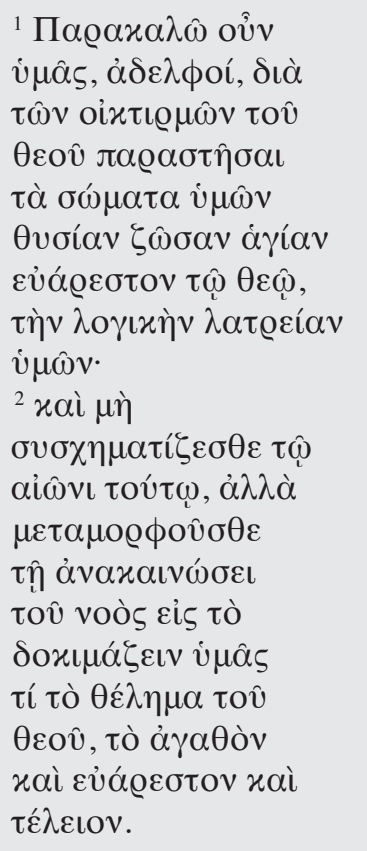 & $\begin{array}{l}\text { Lv 1:1- 2:16; SI 27:6; 40:6; } \\
\text { 50:14-23; 96:8; 107:22; } \\
\text { 116:17. }\end{array}$ & $\begin{array}{l}{ }^{1} \text { Exorto-vos, pois, irmãos, } \\
\text { pelas misericórdias de } \\
\text { Deus, que apresenteis } \\
\text { o vosso corpo como } \\
\text { sacrifício vivo, santo e } \\
\text { agradável para Deus, o } \\
\text { vosso culto racional. } \\
{ }^{2} \text { E não vos conformeis } \\
\text { com este século, mas } \\
\text { transformai-vos pela } \\
\text { renovação da vossa } \\
\text { mente, para que vós } \\
\text { experimenteis qual seja a } \\
\text { boa, agradável e perfeita } \\
\text { vontade de Deus. }\end{array}$ & Alusões e ecos à LXX. \\
\hline \multirow{4}{*}{51} & $\mathrm{NA}^{28} \mathrm{Rm}$ 12:9 & LXX Am 5:15 & Tradução NA ${ }^{28}$ & Análise \\
\hline & \multirow{3}{*}{ 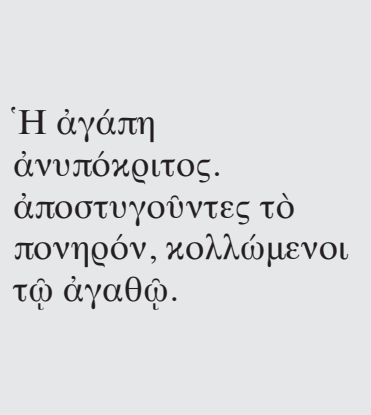 } & 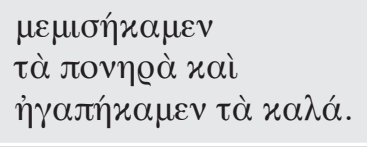 & \multirow{3}{*}{$\begin{array}{l}0 \text { amor sem hipocrisia. } \\
\text { Detestem o mal, estejam } \\
\text { firmados no bem. }\end{array}$} & \multirow{3}{*}{$\begin{array}{l}\text { Ecos da LXX e de SI } \\
\text { 97:10; 101; Pv 3:7. }\end{array}$} \\
\hline & & SI 36:27 & & \\
\hline & & 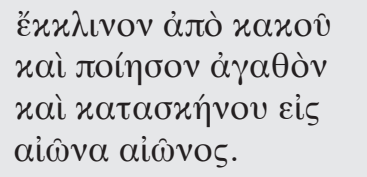 & & \\
\hline \multirow[b]{2}{*}{52} & $N^{28} \mathrm{Rm}$ 12:15 & LXX Eclo 7:34 & Tradução NA ${ }^{28}$ & Análise \\
\hline & 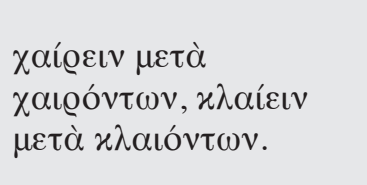 & 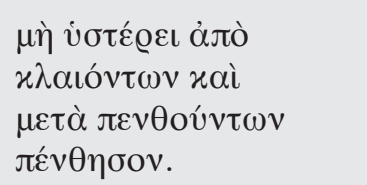 & $\begin{array}{l}\text { Alegrai-vos com aqueles } \\
\text { que se alegram e chorai } \\
\text { com aqueles que choram. }\end{array}$ & Paralelo alusivo à LXX. \\
\hline
\end{tabular}




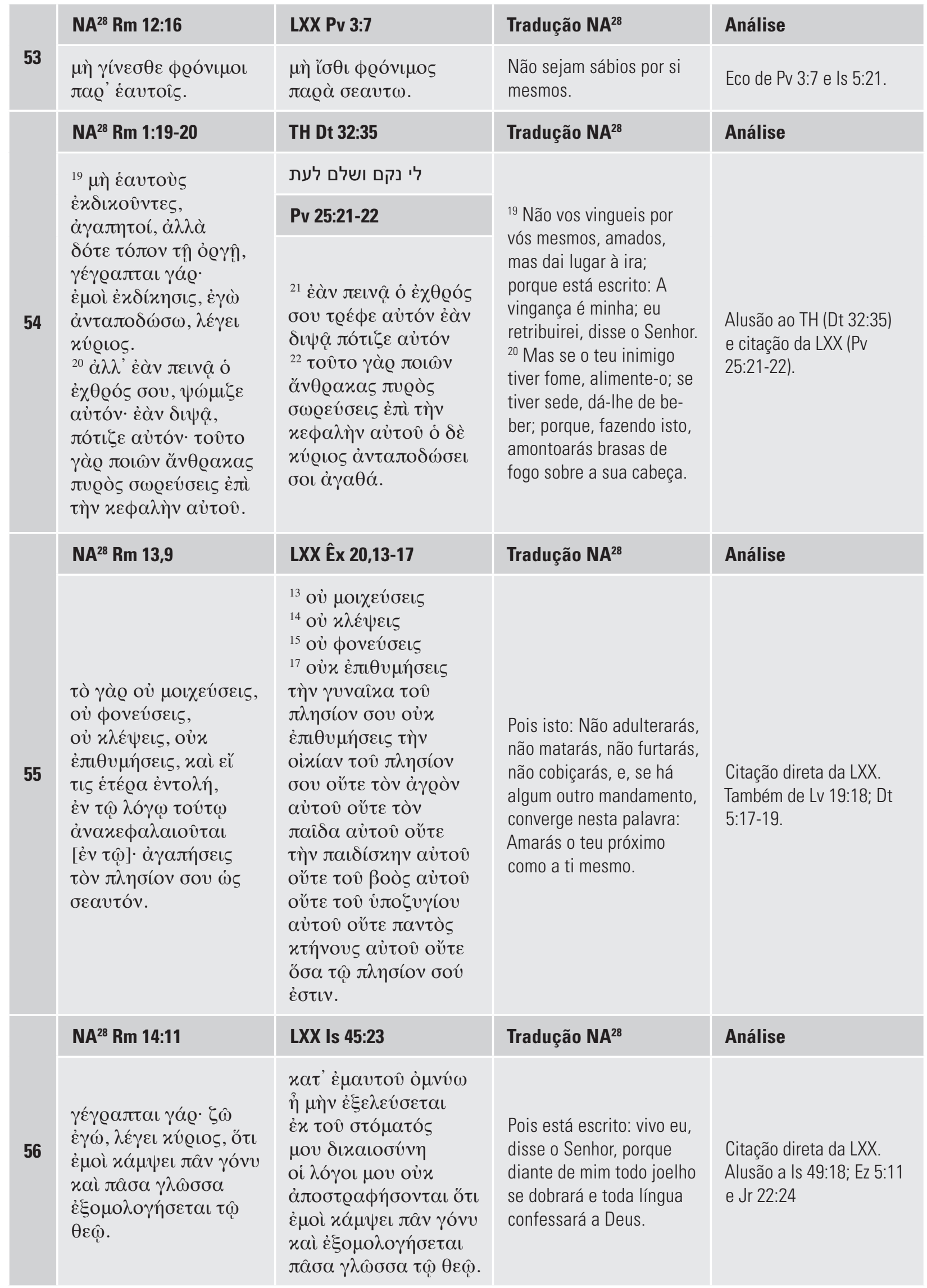




\begin{tabular}{|c|c|c|c|c|}
\hline \multirow{6}{*}{57} & $N^{28} \operatorname{Rm} 15: 8-9$ & LXX 2Sm 22:50 & Tradução NA ${ }^{28}$ & Análise \\
\hline & \multirow{5}{*}{ 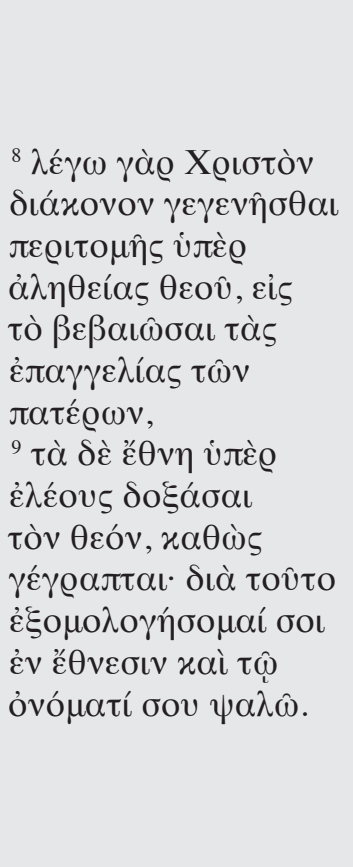 } & 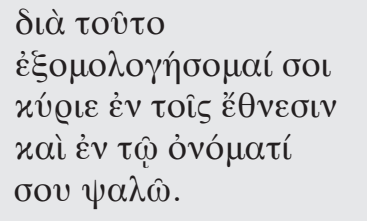 & \multirow{5}{*}{$\begin{array}{l}{ }^{8} \text { Digo, pois, que Cristo foi } \\
\text { constituído ministro da } \\
\text { circuncisão, pela verdade } \\
\text { de Deus, para confirmar } \\
\text { as promessas dos pais; } \\
{ }^{9} \text { e para que os gentios } \\
\text { glorifiquem a Deus por } \\
\text { causa da sua misericórdia, } \\
\text { assim como está escrito: } \\
\text { através disso te glorificarei } \\
\text { entre os gentios e cantarei } \\
\text { louvores ao teu nome. }\end{array}$} & \multirow{5}{*}{$\begin{array}{l}\text { Alusão à Mq 7:20 no v.8 } \\
\text { e Citaçãa direta da LXX } \\
\text { no v. } 9 .\end{array}$} \\
\hline & & SI 17:50 & & \\
\hline & & 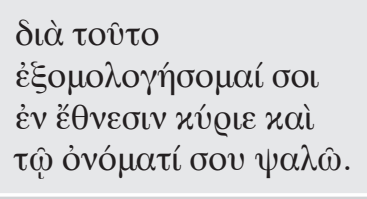 & & \\
\hline & & Mq 7:20 & & \\
\hline & & 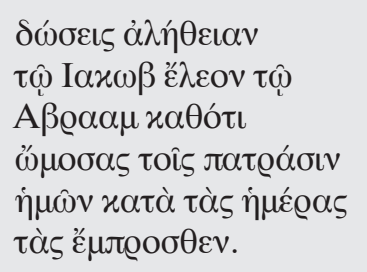 & & \\
\hline \multirow{6}{*}{58} & $N^{28} \operatorname{Rm} 15: 10-12$ & LXX Dt 32:43 & Tradução NA 28 & Análise \\
\hline & \multirow{5}{*}{ 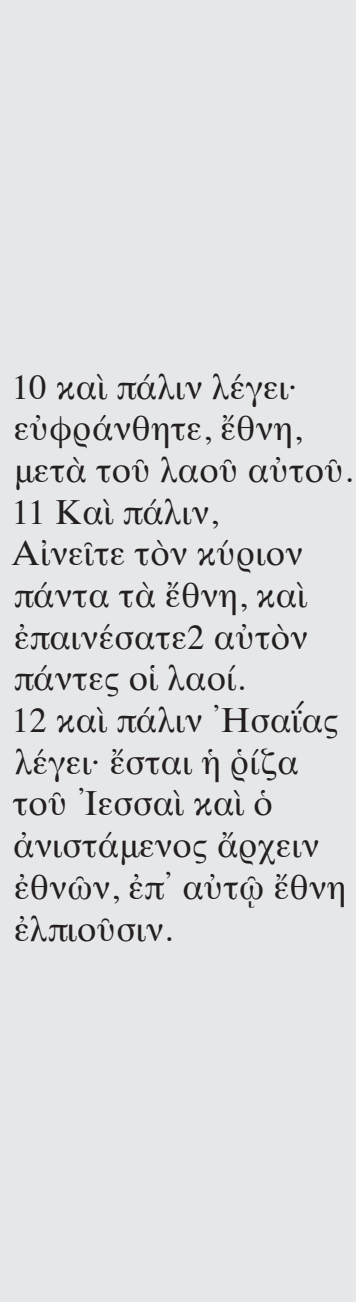 } & 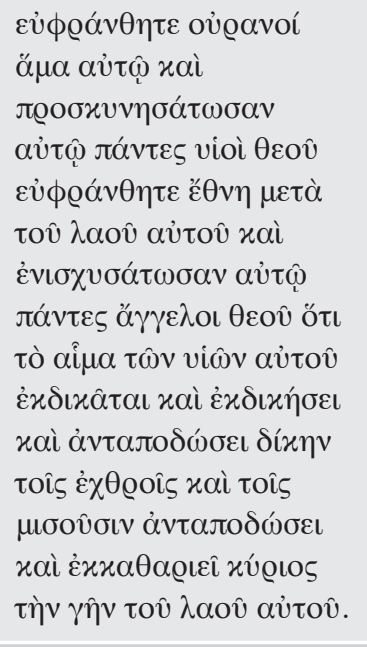 & \multirow{5}{*}{$\begin{array}{l}10 \text { E disse novamente: } \\
\text { Alegrai-vos, ó gentios, } \\
\text { com o seu povo. } \\
11 \text { E ainda: Louvai ao } \\
\text { Senhor, vós todos os } \\
\text { gentios, e todos os povos } \\
\text { o louvem. } \\
\text { Também Isaías diz: ele } \\
\text { será a raiz de Jessé, } \\
\text { aquele que se levanta } \\
\text { para governar os gentios. } \\
\text { As nações terão esperan- } \\
\text { ça nele. }\end{array}$} & \multirow{5}{*}{ Citação direta da LXX. } \\
\hline & & SI 116:1 & & \\
\hline & & 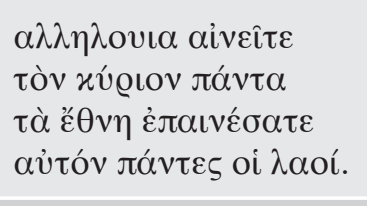 & & \\
\hline & & Is 11:10 & & \\
\hline & & 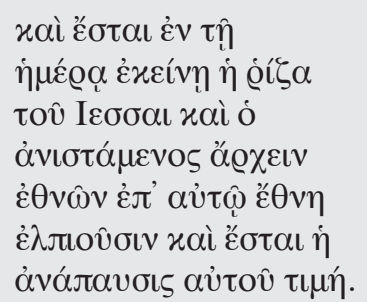 & & \\
\hline
\end{tabular}




\begin{tabular}{|c|c|c|c|c|}
\hline \multirow[b]{2}{*}{59} & NA $^{28} \mathrm{Rm} 15: 21$ & LXX Is 52:15 & Tradução NA 28 & Análise \\
\hline & 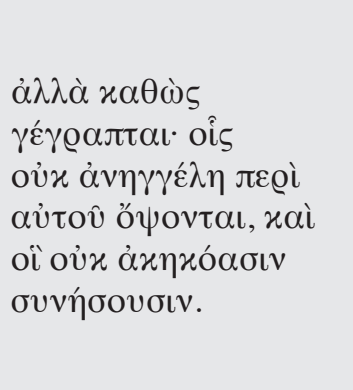 & 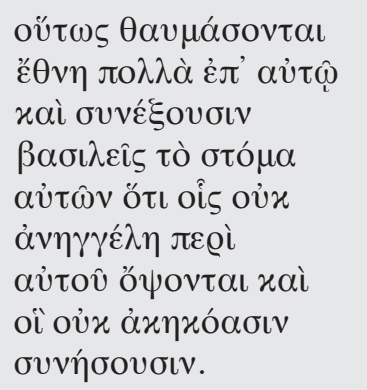 & $\begin{array}{l}\text { Mas, assim como está es- } \\
\text { crito: Aqueles a quem não } \\
\text { foi anunciado, o verão, e } \\
\text { os que não ouviram, o } \\
\text { entenderão. }\end{array}$ & Citação direta da LXX. \\
\hline \multirow[b]{2}{*}{60} & $\mathrm{NA}^{28} \mathrm{Rm} 16,20$ & LXX Gn 3:15 & Tradução NA 28 & Análise \\
\hline & 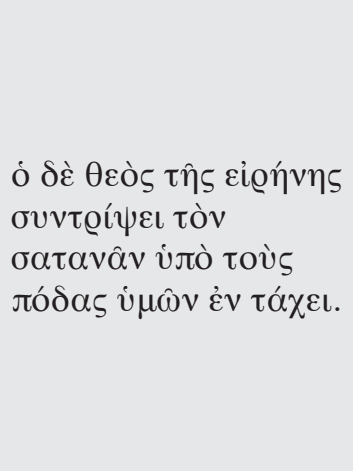 & 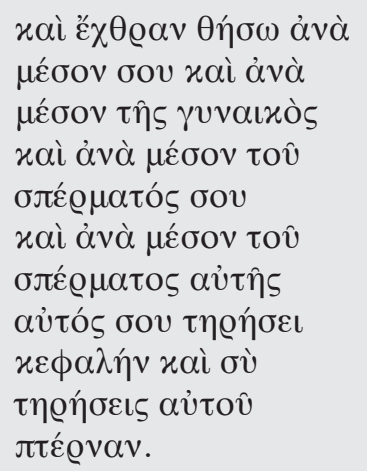 & $\begin{array}{l}\text { E o Deus da paz em breve } \\
\text { esmagará Satanás debai- } \\
\text { xo dos vossos pés. }\end{array}$ & Alusão à LXX. \\
\hline
\end{tabular}

Fonte: elaborado pelo autor

Como podemos conferir ao longo de todo o quadro, o que Paulo evidencia por suas citações, alusões e ecos do AT em sua epístola aos Romanos é que o AT aponta para Cristo. Não é sem razão que Hays propõe "explorar o uso de Paulo da Escritura em sua carta aos Romanos como um meio de se captar a mensagem da epístola" $(1989$, p. 35). Aliás, sem negar a importância das questões históricas, o método do uso do AT no NT admite que o estudo de Romanos pode ser mais proveitoso quando lido como uma conversa entre o apóstolo e os hagiógrafos veterotestamentários, numa leitura de interface entre os dois testamentos, entre a promessa e o cumprimento.

Como bem expressa Del Páramo (1963, p. 229-241), "entre os hagiógrafos do Novo Testamento, ninguém como S. Paulo expôs com tanta ponderação as excelências e utilidades da Sagrada Escritura”. Ao longo de todas as cartas paulinas, o que percebemos é um fragrante perfume da presença do AT, o que demonstra a intimidade que Paulo tinha em relação às Sagradas Escrituras da tradição judaica. Aliás, nenhum autor nos oferece tantas e variadas citações do AT como encontramos nas cartas paulinas, sobremaneira em sua epístola aos Romanos, repleta de citações explícitas, de alusões e de ecos, como podemos conferir no quadro, indicando a fonte; se do grego ou do hebraico.

\section{Considerações finais}

Vale a pena notar alguns dados quantitativos importantes, verificados como resultado desta pesquisa. Primeiramente, quantidade de citações, alusões e ecos do AT em Romanos. Em geral, das 60 referências, 36 são citações, 18 alusões e 6 ecos, com algumas pequenas variações, em que na mesma passagem aparece citação e alusão, por exemplo. No que diz respeito à fonte recorrida, Paulo faz 56 referências ao texto grego da LXX, e 4 ao texto hebraico, caracterizando 
um uso majoritário a partir do texto grego da LXX e não das fontes hebraicas (PITTA, 2014, p. 28; FITZMYER, 1993, p. 34). Porém, em alguns casos não há muita clareza sobre qual foi a fonte exata usada por Paulo, por causa da semelhança de significado do texto entre as duas fontes (LXX e TH) em pontos específicos, como assinalado no quadro.

Uma vez que a epístola aos Romanos tem uma concentração de citações, alusões e ecos, chama ainda mais a atenção o capítulo 9, no qual pelo menos $1 / 3$ das palavras são tomadas direta e explicitamente do AT, além das alusões e ecos. Segundo Belli et al. (2006, p. 161), isso se justifica pelo fato de que "Paulo reflete com e através das Escrituras. Estas não são simples palavras que provam seu discurso, mas o testemunho autorizado de como Deus atua".

Este artigo teve como objetivo analisar o uso do AT na epístola aos Romanos, identificando quando Paulo fez uso de citações explícitas, de alusões ou de ecos de textos veterotestamentários. Em suas mãos o que vemos é que os textos do AT refletem um sentido mais amplo, mais profundo e, muitas vezes, novo, que não encontramos nos rabinos de sua época e nem sempre nos demais hagiógrafos do NT. Tudo isso foi possível porque para Paulo, todo AT era como que um "pedagogo" que conduzia Israel a Cristo (Gl 3:24) e é nos livros do AT que o Apóstolo encontra sua fundamentação para falar do cumprimento das profecias, segundo o que o Deus de Israel havia prometido.

\section{Referências}

ARCHER, G.; CHIRICHIGNO, G. Old Testament Quotations in the New Testament. Chicago: The Moody Bible Institute, 1983.

BEALE, G. K. Manual do Uso do Antigo Testamento no Novo Testamento: exegese e interpretação. São Paulo: Vida Nova, 2013.

BEETHAM, C. A. Echoes of Scripture in the Letter of Paul to the Colossians. Leiden, Holanda: Koninklijke Brill, 2008.

BELLI, F.; CARBAJOSA, I.; ESTRELLA, C. J.; NAVARRO, L. S. Vetus in Novo: el recurso a la Escritura en el Nuevo Testamento. Madri: Ediciones Encuentro, S.A., 2006.

DEL PÁRAMO, S. La Citas de los Salmos en s. Pablo. In: Analecta Biblica 17-18. Studiorum Paulinorum Congressus Internatinalis Catholicus 1961. Pontificio Instituto Biblico (Org.). Roma: E. Pontificio Instituto Biblico, 1963, p. 229-241.

DUNN, J. D. G. Romans 1 - 8. Word Biblical Commentary 38A. Dallas: Word Books, 1988.

FITZMYER, J. A. Romans: a new translation with introduction and commentary. The Anchor Bible 33. New York, Doubleday, 1993.

GONZAGA, W. Compêndio do Cânon Bíblico: listas bilíngues dos Catálogos Bíblicos - Antigo Testamento, Novo Testamento e Apócrifos. Petrópolis, RJ: Vozes: Rio de Janeiro: Editora PUC Rio, 2019.

GONZAGA, W. O Corpus Paulinum no Cânon do Novo Testamento. In: Atualidade Teológica, Rio de Janeiro: PUC-Rio, 2017, p. 19-41.

HAYS, R. B. Echoes of Scripture in the Letters of Paul. New Haven e Londres: Yale University Press, 1989. 
LÉGASSE, S. Lépître de Paul aux Romains. Paris: CERF, 2002.

MOO, D.J. Comentário a la espístola de Romanos. Barcelona: Editorial CLIE, 2014.

PENNA, R. Carta a los Romanos: Introducción, versión y comentario. Navarra: Verbo Divino, 2013.

PITTA, R. Lettera ai Romani: Nuova versione, intrdouzione e commento. Milano: Paoline, 2014.

RATZINGER, J. La Interpretación Bíblica en Conflicto. Almudi.org, 19 maio 2010. Disponível em: $<$ http://bit.ly/2NZTPP5>. Acesso em: 17 out. 2019.

ROBERTSON, A. W. El Antiguo Testamento en el Nuevo. Buenos Aires: Nueva Creación; Grand Rapids: William B. Eerdmans Publishing Co., 1996.

SCHLIER, H. La lettera ai Romani: testo grego, traduzione e commento. Brescia: Paideia, 1982.

SEIFRID, M. A. Romanos. In: BEALE, G. K.; CARSON, D. A. (Orgs.). Comentário do Uso do Antigo Testamento no Novo Testamento. São Paulo: Vida Nova, 2014. p. 759-864.

SILVA, M. O Antigo Testamento em Paulo. In: HAWTHORNE, G. F.; MARTIN, R. P.; REID, D. G. (Orgs.). Dicionário de Paulo e suas Cartas. São Paulo: Paulus; Edições Vida Nova e Edições Loyola, 2008. p. 76-92.

STANLEY, C. D. Paul and the Language of Scripture: citation technique in the Pauline epistles and contemporary literature. Cambridge: Cambridge University Press, 1992.

WILCKENS, U. La carta a los Romanos: Rom 1-5, v. I. Salamanca: Sígueme, 1997. 